\title{
Assessment of Dam-Induced Changes in Ecogeomorphological Behaviour and Fluvial Functionality in the Damodar River, West Bengal, India
}

Sandipan Ghosh ( $\square$ sandipanghosh19@gmail.com )

Chandrapur College https://orcid.org/0000-0002-0748-8729

Md. Mofizul Hoque

Aliah University

Ujwal Deep Saha

Vivekananda College for Women

Aznarul Islam

Aliah University

\section{Research}

Keywords: Ecogeomorpholoy, Fluvial Functionality Index, Environmental flow, River metamorphosis, Floodplain classification, Damodar River

Posted Date: November 2nd, 2021

DOI: https://doi.org/10.21203/rs.3.rs-1002245/v1

License: (c) (i) This work is licensed under a Creative Commons Attribution 4.0 International License. Read Full License 


\section{Abstract}

Anthropogenic interventions in the form of dams and barrages often alter the fluvial functionality and ecogeomorphological (geomorphology, hydrology, and ecology) behaviour of the river systems. The present work examines the environmental flow, channel metamorphosis, and fluvial functionality of Damodar River in the context of Damodar Valley Corporation (DVC) dams and development. The structural (dams, barrages, weirs, etc.) and non-structural (urban-industrial and agricultural disposal with effluents, sand mining, etc.) interventions hinder the ecological functionality of the river. This study portrays that the eco-geomorphological behaviour and fluvial functionality of the river have changed due to flow alteration and diversion by dams and barrages and due to the urban-industrial and agricultural growth in the basin area. These changes have affected riverine ecological integrity. The ecological functionality level of this study area ranges from 85 to 181 i.e. poor to good-fair. The ecological functionality level in sample channel sections (i.e., immediate upstream and downstream of Durgapur Barrage) is poor, and the value ranges from 61 to 100 due to the hydrological impact of the barrage and the Durgapur urban-industrial belt. This assessment work would help to restore the fluvial environment for humans as well as riverine biota.

\section{Introduction}

It has been a long-running debate regarding the commencement of 'Anthropocene' and whether to include it in the geological timescale or not (Monastersky 2015). Aside from it, researchers from various fields of study have agreed that human actions (both directly and indirectly) have placed significant signals of human dominance as a geological agent on every sphere of the Earth's atmosphere. With increasing anthropogenic pressure on the natural environment, an urge of integrating different disciplines has been often seen among researchers for conserving the environment (Thomas and Parsons 2002). As a part of this philosophy, since the late 90's the fluvial systems were being started thinking from an ecosystem perspective; eco geomorphology (Thomas and Parsons 2002; Tare et al. 2017). Here, apart from the physical, chemical, and ecological components, longitudinal, lateral, and vertical components of a river and its floodplain were also considered as components useful in conserving the river ecosystem (Ward 1989).

Considering only the natural flow arteries of water, the direct impoundments within its regime (transverse intervention) during the latter half of the 20th century jumped up to a certain horizon where each day has registered two newly constructed dams start functioning (Richter and Thomas 2007). Although, these dams and other river water storage infrastructure have been contributing largely to substantial benefits of the human society it had come at a great cost of degrading the geomorphic, hydrological, and ecological health (Resh et al. 1988). The all hailed consequence of dam construction is that the river gets thrown away from the state of stability is achieved by that time (Ghosh and Guchhait 2014a). The loss of geomorphic connectivity due to the construction of dams and barrages between the upstream and downstream parts of a fluvial system has largely affected the ecology (both channel and riparian) (Ligon et al. 1995; Kingsford 2000; Schmutz and Moog 2018), sediment budgeting (Vinh et al. 2014), water chemistry (Zhong and Power 1996), flow pulses and floodplain processes (Graf 2006; Wiejackza et al. 2014; Biswas and Pani 2021) while converting a natural hydrological regime to a regulated one. As a cumulative term, it alters or modifies the functioning of the physical entity.

The Damodar, a tropical river, flowing over the Rarh plains on the eastern part of India bears a century-long history of human regulation (both transverse and lateral). Primarily, the human impoundments were aimed mainly for flood control and agricultural development (Bhattacharya 2011) but later the comprehensive enactment of river-related planning in the Damodar River Basin was introduced to develop its vast depository of resources in an integrated way. It was a comprehensive plan aimed for multipurpose management where the trunk channel and its tributaries were tamed and regulated for utilising its water resources. These large-scale taming was done using river training engineering structures including dams, barrages, weirs, sluices, and embankments. The works of Ghosh and Guchhait (2014b, 2016) and Singh et al. (2020) have shown the significant alterations of flow condition of Damodar and shift from its morphological stability as a direct consequence of such impoundments.

Although scientific researches on the impact of dams and barrages on the fluvial environment started increasing simultaneously with an increase in the number of dams and barrages getting installed globally but only since the late ' 90 s, several workers started focusing on the ecological impact of these structures (Opperman et al. 2019). Several works have indicated the degradation of ecological health and ecosystem services due to dam construction as it regulates the extreme flow condition (both low and high). This, in return, throws the system away from its naturality, both geomorphologically and in terms of ecosystem services. The deviations of the fluvial processes of the Damodar River from its naturality in terms of its geomorphological and ecological functionality were one of the unattained perspectives that urge a comprehensive understanding. A venture of this sort requires such a methodological outlook where the extent and intensity of naturality loss could be grasped through the integration of morphological, sedimentological, hydrological, and ecological characteristics existing within the floodplain and active channel belt. In this study, the fluvial process and its response to direct channel impoundment have been assumed to be existing in close accordance with the ecosystem services and riverine ecology. Thus, it integrates floodplain development and the nature of ongoing fluvial processes with the ecological characteristics of the active channel belt.

\section{Study Area}


Damodar River is one of most important rivers in Jharkhand and West Bengal, covering the terrain of eastern Chhotanagpur Plateau, lateritic Rarh plain and Quaternary to Recent alluvial floodplains of the Bengal Basin. Damodar river basin (DRB) is the sub-basin of river Ganga, having a funnel-shaped basin. The total catchment area of this funnel-shaped basin is about $23,371 \mathrm{~km}^{2}$, covering the states of $\mathrm{Jharkhand}$ ( $73.7 \%$ ) and West Bengal (26.3\%) in India (Majumder et al. 2010). The Damodar and its main tributary- the Barakar cover about 40 percent area of the Damodar valley region which is the core area of the DVC. Barakar joins Damodar after traveling about $241 \mathrm{~km}$. And the other tributaries and subtributaries of this river are Konar, Bokaro, Haharo, Jamunia, Ghari, Guaia, Khadia and Bhera, etc. Once Damodar River was known as the sorrow of Bengal as several devastating floods occurred in the lower Damodar Basin due to torrential rainfall $\left(<1300 \mathrm{~mm}^{-1} \mathrm{ear}^{-1}\right)$ and siltation in the channel area, but now 'river of sorrow' has turned into the 'river of agony' due to dominance of escalating human pressure and environmental degradation in Anthropocene. It is a major rain-fed river of eastern India, influenced by south-west monsoonal regimes and tropical cyclones. This rainfed river rises from the Khamarpet hill near Chandwa village in Latehar district of Jharkhand approximately at $23^{\circ} 37^{\prime} \mathrm{N}$ latitude and $84^{\circ} 41^{\prime} \mathrm{E}$ longitude (Sen 1985; Chandra 2003; Bhattacharyya 2011; Ghosh 2014). The total length of this river is about $592 \mathrm{~km}$, and the average discharge rate of this river is about $296 \mathrm{~m}^{3} \mathrm{~s}^{-1}$ (measured at Rhondia Weir, Purba Barddhaman). It is one of most polluted rivers in India, as the basin is home to heavy industries, mining activity, and populated regions.

The geographical extension of this basin is between $22^{\bullet} 15^{\prime}$ to $24^{\bullet} 30^{\prime} \mathrm{N}$ latitude and $84^{\bullet} 30^{\prime}$ to $88^{\bullet} 15^{\prime}$ E longitude. According to Hora (1947), the entire Damodar valley is divided into three segments such as the upper, middle and lower valleys based on the gradient of the river. The river slope is about $1.89 \mathrm{~m} \mathrm{~km}^{-1}$ during the first $241.35 \mathrm{~km}$, about $0.568 \mathrm{~m} \mathrm{~km}^{-1}$ during the next $160.9 \mathrm{~km}$, and about $0.189 \mathrm{~m} \mathrm{~km}{ }^{-1}$ during the last $144.8 \mathrm{~km}$. The undulating upper plateau terrain and the middle valleys are wider than the flat lower alluvial valley. The Damodar River in its upper reaches flows over plateau followed by a flat alluvial plain in the southeast and eastward towards the Bay of Bengal. The region is richly endowed with varied mineral resources. The upper and middle catchment areas cover about 4/5th of the total catchment area which is hilly terrain with a steep slope while the lower valley is narrow, gently dipped and flat. During heavy monsoonal rain in the upper valley the river has a natural tendency of overflow the excess runoff water in the lower alluvial plain.

\section{Materials And Methods}

\subsection{Data Sources}

Quaternary to Recent floodplains, and the channel bed of the Damodar River (West Bengal, India) are gradually developed by the complex interactions of fluvial hydrogeomorphic processes and anthropogenic processes but their characteristics and genetic evolution are essentially the product of stream power, channel dimensions, and sediment character (Ghosh, 2016). Empirical observation of these processes and landforms is an approach by which the geomorphologists practice their knowledge and experience to identify the assemblage of landforms or planform features that make up rivers, develop hypotheses to interpret the processes responsible for those landforms, determine how those features have adjusted and changed over time, and, finally, place this understanding in its spatial and temporal context (Fryirs and Brierley 2013; Ghosh, 2016). In this context, geomatics is applied to deal with the quantitative analysis of channel dimensions, and the geomorphic classifications of streams and floodplains with the help of GIS (geographic information system) and remote sensing software (i.e., Erdas Imagine 2014, ArcMap 10.4, and Global Mapper 21.0), and Google Earth Pro Engine. The basic spatial information of the Damodar Basin was collected from the topographic sheets of scale RF 1:50,000 (i.e., 73 M/5, M/7, M/11, M/12, M/15, and M/16). The main satellite image information (WGS84 datum and UTM projection) was gathered and processed from the multispectral bands of Landsat MSS (collected from https://earthexplorer.usgs.gov/; path/row 149/44; date of image: 22-02-1973), IRS Resourcesat 2 LISS III (https://bhuvan-app3.nrsc.gov.in/data/download/index.php; path/row - 106/55, and 177/55, date of image: 06-01-2019) and Sentinal 2A (collected from https://earthexplorer.usgs.gov/; tile number - T45QWF and T45QWG; date of image: 06-08-2021). The digital elevation model (DEM) is created using SRTM 30 m (collected from https://earthexplorer.usgs.gov/; date: 23-09-2014) and Cartosat-1 10 m version 2 (collected from data repository of NRSC-ISRO, Hyderabad; date: 27-12-2014) for the analysis channel dimensions. It is needed to mentioned that the elevation accuracy of Cartosat-1 DEM $1.98 \mathrm{~m}$ in the alluvial plains (Agarwal et al., 2020). For the study of daily, monthly and annual discharge variability (station: Durgapur Barrage and Rhondia Weir) the pre-dam and post-dam flow data is collected from the works of Bhattacharyya (2011), Ghosh and Guchhait (2016), Verma et al. (2015 and 2017), and Mitra and Singh (2018).

\subsection{Metholodology}

\subsubsection{Geomorphic Classification of Channel and Floodplain}

The classification of natural channel and floodplain is an essential geomorphic tool for the process-from paradigm, and the basic belief is that the fluvial forms imply processes (Buffington and Montgomery, 2013). The classification scheme is used to simplify the complex river continuum of fluvial processes and conditions within a landscape unit by identifying places that function in a similar manner. In this context, the main goal is to classify channels and floodplains for predicting response to anthropogenic disturbance (i.e., dams and barrage) and designing river style framework. The spatial scale of study varies from $10^{1} \mathrm{~m}$ (reach system) to $10^{3} \mathrm{~m}$ (stream system), having average time frame of 50 years (1970 -

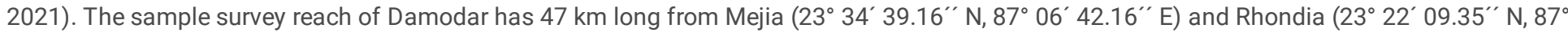
$\left.28^{\prime} 17.29^{\prime \prime} \mathrm{E}\right)$, having a river impoundment of barrage at middle. The riverbed elevation difference between two extreme points is $23 \mathrm{~m}$, and the 
estimated average channel gradient is $0.489 \mathrm{~m} \mathrm{~km}^{-1}$. One of most widely used hierarchical channel classification scheme, developed by Rosgen (1994), is applied here taking into considerations of physical processes (e.g., bed load transport, bank erosion etc.), morphology (e.g., sinuosity index, entrenchment ratio, width-depth ratio etc.), and biological inventories (e.g., vegetation, aquatic organisms tec.) (USDA, 2007; Buffington and Montgomery, 2013; Mechan and O'Brien, 2019). In this scheme the channels are sub-divide into 94 minor channel types as a function of slope and grain size. In short, Rosgen classification generates four level of channels - (a) Level I Geomorphic characterization (stream types 'A through G'); (b) Level II Morphological description (stream types 'A1 - A6' through 'G1 - G6'); (c) Level III stream 'state' or condition; and (d) Level IV validation level. Another genetic classification scheme, developed by Nanson and Croke (1992), is applied to recognize the floodplain type, considering the hypothesis - the floodplains are formed by a complex interaction of fluvial processes but that character and evolution is essentially the product of stream power and sediment character. Based on specific stream power, sediment type, erosion and deposition processes, landforms, channel planform and environment, fifteen types of floodplains can be identified. Both classification schemes of Damodar serve three purposes of Anthropocene River - (a) prediction of river's behaviour from its appearance; (b) development of specific hydraulic and sediment relations for a given morphological channel type and state; and (c) getting an idea of river metamorphosis.

\subsubsection{Stream Data Collection and Geomorphic Indices}

The key channel dimensions, viz., cross-section and longitudinal profile, are measured both manually and digitally using survey instruments and GIS. The cross-section of a channel and short long profile of river bed Leica Sprinter $250 \mathrm{~m}$ laser level and survey staff to record elevations and distances across the entire valley, specifically identifying the edge of the terrace, flood-prone area, bankfull heightand thalweg (figure 1). Using geomatics, the cross-profile of channel is derived from the Cartosat-1 $10 \mathrm{~m}$ DEM with the help of Global Mapper 21 3D path profile tool settings. The elevation corridor type is set to keep maximum elevation along perpendicular (sample number along the corridor is maximum, so that it captures the full $10 \mathrm{~m}$ resolution of DEM), and the distance from path is set to a large distance of 1000 meters. The elevation profile dataset is transformed into gird format, and the data is exported to MIKE 21 hydrologic software for estimating mean cross-sectional area of channel ( $A_{b c}$ assuming channel follows the form of trapezoid). In each study unit (i.e., sample reach) five cross-profiles are prepared to get average value of area, and the volumetric flow rate $\left(Q_{\text {max }}\right)$ of trapezoid channel is calculated in MIKE 21 software. The value of $Q_{\text {max }}$ is measured at bankfull stage which is the elevation of the floodplain adjacent to the active channel, and the value reflects the maximum flood flow (i.e., maximum carrying capacity), passing through channel. The reach is morphologically analyzed in two parts (taking nine sections) - (a) upstream of Durgapur Barrage reservoir (0 to $25.09 \mathrm{~km}$ ) and (b) downstream of Durgapur Barrage reservoir $(25.09-47 \mathrm{~km})$ to trace the impact of flow regulation and sediment load variation. In each section (S1 to S9) the following morphological parameters are estimated using Cartosat110 m DEM and Sentinal 2A image (10 m resolution) in the GIS platform of ArcMap 10.4 and Global Mapper 21: (1) maximum channel depth ( $\left.D_{\text {max }}\right)$, (2) average channel depth $\left(D_{\text {avg }}\right)$, (3) bankfull channel width $\left(W_{b}\right)$, (4) channel bottom width $\left(W_{b t}\right)$, (5) flood-prone width ( $\left.W_{f}\right)$, (6) channel cross-sectional area at bankfull stage $\left(A_{b c}\right)$, (7) hydraulic radius at bankfull stage $(R),(8)$ channel width-depth ratio (W/D), (9) entrenchment ratio (ER), (10) sinuosity index (SI), (11) braid-channel ratio (BR), and (12) channel gradient (s) (Table 1). 
Table 1

Important hydrogeomorphic indices applied in the study area

\begin{tabular}{|c|c|c|c|}
\hline $\begin{array}{l}\text { SI } \\
\text { No }\end{array}$ & Index & Formula and Description & Source \\
\hline 1 & $\begin{array}{l}\text { Sinuosity Index (SI) } \\
\text { It is a measure of a stream's crookedness, relating with steep } \\
\text { - low slope }\end{array}$ & $\begin{array}{l}S I=L_{c m a x} / L_{R} \\
L_{R} \text { is the overall length of the channel belt reach measured } \\
\text { along a straight line; } \\
L_{c m a x} \text { is the mid-channel length of the same reach or the } \\
\text { mid-channel length of the widest channel, where there is } \\
\text { more than one channel }\end{array}$ & $\begin{array}{l}\text { Friend } \\
\text { and } \\
\text { Sinha } \\
(1993)\end{array}$ \\
\hline 2 & $\begin{array}{l}\text { Braid-channel Ratio (BR) } \\
\text { It is a measure of development intensity of multiple distinct } \\
\text { channels, braided channel }\end{array}$ & $\begin{array}{l}B R=L_{c t o t} / L_{c m a x} \\
L_{c m a x} \text { is the mid-channel length of the widest channel } \\
\text { through the reach } \\
L_{c t o t} \text { is the sum of the mid-channel lengths of all the } \\
\text { segments of primary channels in a reach }\end{array}$ & $\begin{array}{l}\text { Friend } \\
\text { and } \\
\text { Sinha } \\
(1993)\end{array}$ \\
\hline 3 & $\begin{array}{l}\text { Entrenchment Ratio (ER) } \\
\text { It is a field measurement of channel incision in a floodplain }\end{array}$ & $\begin{array}{l}E R=W_{f} / W_{b} \\
W_{f} \text { is the flood-prone width, measured at the elevation of } \\
\text { twice the maximum depth at bankfull } \\
W_{b} \text { is the bankfull width of the channel }\end{array}$ & $\begin{array}{l}\text { Rosgen } \\
\text { (1994) }\end{array}$ \\
\hline 4 & $\begin{array}{l}\text { Width-Depth Ratio (W/D) } \\
\text { It is key to understanding the distribution of available energy } \\
\text { within a channel and the ability of various discharge }\end{array}$ & $\begin{array}{l}W / D=W_{b} / D_{a v g} \\
W_{b} \text { is the bankfull width of the channel } \\
D_{\text {avg }} \text { is the mean bankfull depth }\end{array}$ & $\begin{array}{l}\text { Rosgen } \\
\text { (1994) }\end{array}$ \\
\hline 5 & $\begin{array}{l}\text { Mass Flow Rate }\left(Q_{\max }\right) \\
\text { It is the rate of water volume passing in unit time from a } \\
\text { channel section. The trapezoidal open channel calculation } \\
\text { uses the Manning equation. }\end{array}$ & $\begin{array}{l}\text { Qmax }=A_{b c} \cdot V \\
V=1 / n \cdot R^{2 / 3} \cdot s^{1 / 2} \\
A_{b c} \text { is the bankfull cross-sectional area } \\
V \text { is the flow velocity } \\
n \text { is manning roughness coefficient }(0.025-0.035) \\
R \text { is the hydraulic radius of cross-section }\end{array}$ & $\begin{array}{l}\text { Chow et } \\
\text { al. } \\
\text { (1988) }\end{array}$ \\
\hline
\end{tabular}

\subsubsection{Fluvial Functionality Index}

The methodology of fluvial functionality index (FFI) has a holistic approach (Siligardi and Cappelletti, 2006; Siligardi, 2007) to include key environmental sectors (biotic association, water quality, biological diversity, anthropogenic impact etc.) as well as hydrogeomorphic sectors (floodplain width, bed roughness, flow variability etc.) for the restoration of fluvial ecosystem, riparian flora and fauna in harmony with human. The FFI report card is applied in nine channel sections or units of Damodar River, from Mejia to Rhondia (47 km stretch), to characterize the expected ecological functioning level using current Sentinal 2A image (7th June, 2021), Google EarthPro Engine and field database. The field survey was conducted from 10th to 13th February, 2021, considering right and left floodplains of each unit from Mejia to Rhondia. That final report card comprises fourteen pertinent questions concerning the hydrogeomorphic and ecohydrological characteristics of the channels which may be controlled or influenced by the Durgapur Barrage and surrounding urban-industrial complex (Table 2). In the FFI report card each of the questions' replies are assigned weighted numbers grouped in to 4 classes (maximum score 40 and minimum score 1) that reflect the functional differences between individual answers (Siligardi, 2007). The FFI score obtained by adding the partial scores relevant to each question, can range from the smallest value of 14 to a maximum 300 (Siligardi, 2007). The final score of each reach is matched with the five functionality levels (having conventional colour codes), expressed as I (best situation) to V (worst situation). After that, it is necessary to have a thematic outlook of FFI score to get entire perspective of fluvial functional zones at current condition. The FFI can used as instrument for the scale management of a river stretch within the domain of landscape ecology which focuses mainly on ecological structure (spatial relations between distinct ecosystems), function (interaction between spatial elements such as energy flows, materials and individuals) and change (alteration in structure and function of ecomosaic) (Siligardi and Cappelletti, 2006). 
Table 2

A brief tabulation of fluvial functioning index card applied in the Damodar River

\begin{tabular}{|c|c|c|c|}
\hline Questions & Main Theme & Objectives & Principles \\
\hline $\begin{array}{l}1 \\
\text { (Max } \\
\text { Score: } 25\end{array}$ & $\begin{array}{l}\text { Land use pattern } \\
\text { of surrounding } \\
\text { area }\end{array}$ & $\begin{array}{l}\text { Indirectly evaluate the repercussions on river } \\
\text { functionality induce by land use modifications that } \\
\text { can affect sediment supply, diffuse of organic } \\
\text { materials, nutrients and pollutants }\end{array}$ & $\begin{array}{l}\text { The presence of urban areas or industries or } \\
\text { agricultural practices strongly influence the overall } \\
\text { environment of river, and the river is used as } \\
\text { receptable for urban and industrial waste. }\end{array}$ \\
\hline \multicolumn{4}{|l|}{$\begin{array}{l}\text { Min } \\
\text { Score: 1) }\end{array}$} \\
\hline $\begin{array}{l}2 \\
\text { (Max } \\
\text { Score: } 40 \\
\text { Min }\end{array}$ & $\begin{array}{l}\text { 2: Vegetation } \\
\text { present in the } \\
\text { primary } \\
\text { perifluvial zone } \\
\text { (PPZ) }\end{array}$ & $\begin{array}{l}\text { Observed the features in terms of composition and } \\
\text { structure of vegetation formations in the perifluvial } \\
\text { zone; to evaluate the presence of vegetation } \\
\text { formations functions efficiently (habitat } \\
\text { constitution, auto purifying capacity, thermal } \\
\text { regulation, food supply and water stabilization of }\end{array}$ & $\begin{array}{l}\text { The artificialization of streams and the adjacent } \\
\text { territory determines the ecological gradient linked to } \\
\text { the river, reduction in present vegetation typologies, } \\
\text { simplification of complex structural models, and } \\
\text { presence of functional riparian zone }\end{array}$ \\
\hline
\end{tabular}

Min
Score: 1) 2b: Vegetation regulation, food supply and water stabilization of present in the secondary perifluvial zone (SPZ)

\section{$3 \quad$ Width of the \\ Evaluate the cumulative width of complex} functional

$\begin{array}{ll}\text { (Max } & \text { formations } \\ \text { Score: } 15 & \text { present in the }\end{array}$

Score: $15 \quad \begin{aligned} & \text { present in the } \\ & \text { perifluvial zone }\end{aligned}$

Min

Score: 1)

4

$4 \quad \begin{aligned} & \text { Continuity of } \\ & \text { functional }\end{aligned}$

Max formations

Score: 15 present in the

Min perifluvial zone

Score: 1)

$5 \quad$ Water conditions

for environmenta

(Max sustainability

Score: 15

Min

Score: 1)

6 Flow efficiency

(Max

Score: 25

Min

Score: 1)

$7 \quad$ Riverbed

Max substrate and

Score: $25 \quad$ structures of

Min trophic matter

Score: 1)

$8 \quad$ Erosion

Max

Score: 20

Min

Score: 1) formations (community of plant organisms) present in the primary and secondary perifluvial zone; PPZ river bed and surrounding territory and SPZ artificialized river bed

Evaluate the continuity of vegetation and more specifically of the total functional formation precedent in both zones
Evaluate the repercussions on functionality of the rate of flow determined by the hydrological regime in the sample reach; hydrological regime is determined by climatic, morphological and anthropogenic factors
Evaluate the possibility of flooding and its potential efficiency (in space - time frame), function of the extension of the flooded portion, by the frequency of flooding and duration of water stagnation
The efficiency of vegetation observed in structuring of complementary formations; minimum level of formations in perifluvial zone is $30 \mathrm{~m}$ width
The gaps in the ecological continuum be either natural or man-made can compromise at different levels of ecological functions explicated
Frequency and intensity of the daily, monthly and annual peak flow have direct impact on the colonization of the plant and animal communities; flow variation impact on trivialisation of habitat and aquatic diversity, reduction in self purifying ability and alteration in erosion /deposition sequence

The presence of vast flooded areas is to be considered a fundamental element for attaining and optimal functionality of the fluvial ecosystem, creating condition for riparian vegetation

$$
\text { creating condition for riparian vegetation }
$$
territory determines the ecological gradient linked simplification of complex structural models, and to 


\begin{tabular}{|c|c|c|c|}
\hline Questions & Main Theme & Objectives & Principles \\
\hline $\begin{array}{l}9 \\
\text { (Max } \\
\text { Score: } 20 \\
\text { Min } \\
\text { Score: 1) }\end{array}$ & Cross-section & $\begin{array}{l}\text { Evaluate the morpho-structural diversity of the } \\
\text { cross-section on the river profile from bank to bank, } \\
\text { following anthropogenic changes }\end{array}$ & $\begin{array}{l}\text { A natural river bed or valley usually has a high } \\
\text { morpho-structural diversity with a gradual } \\
\text { transition from aqueous to terrestrial ecosystem }\end{array}$ \\
\hline $\begin{array}{l}10 \\
\text { (Max } \\
\text { Score: } 25 \\
\text { Min } \\
\text { Score: 1) }\end{array}$ & $\begin{array}{l}\text { Ichthyic } \\
\text { suitability }\end{array}$ & $\begin{array}{l}\text { Evaluate the suitability of the homogenous stretch } \\
\text { to accommodate the vocational fish fauna; } \\
\text { availability of areas for fish reproduction, nursery } \\
\text { growth, hiding places etc. }\end{array}$ & $\begin{array}{l}\text { The presence of stabilised areas is an essential } \\
\text { feature for specific fish population; the presence of } \\
\text { transverse barriers is obstacle to fish migration }\end{array}$ \\
\hline $\begin{array}{l}11 \\
\text { (Max } \\
\text { Score: } 20 \\
\text { Min } \\
\text { Score: 1) }\end{array}$ & $\begin{array}{l}\text { Hydrogeomorphic } \\
\text { characteristics }\end{array}$ & $\begin{array}{l}\text { Evaluate the morphological diversification of river } \\
\text { bed at both macro scale and meso scale, produced } \\
\text { by natural occurrence of hydrologic and geomorphic } \\
\text { processes }\end{array}$ & $\begin{array}{l}\text { Good pools/riffles sequence and anastomose } \\
\text { channels are the areas with greater production of } \\
\text { biomass; }\end{array}$ \\
\hline $\begin{array}{l}12 \\
\text { (Max } \\
\text { Score: } 15 \\
\text { Min } \\
\text { Score: 1) }\end{array}$ & $\begin{array}{l}\text { Plant component } \\
\text { in wet river bed }\end{array}$ & $\begin{array}{l}\text { Evaluate the eutrophication of a river which reflects } \\
\text { itself in the production of one thick periphytic felt- } \\
\text { like growth }\end{array}$ & $\begin{array}{l}\text { It has an important effect on the speed of the river, } \\
\text { the abrasive capacity of stream, the turbidity of } \\
\text { water, shading and type of substrate etc. }\end{array}$ \\
\hline $\begin{array}{l}13 \\
\text { (Max } \\
\text { Score: } 15 \\
\text { Min } \\
\text { Score: 1) }\end{array}$ & Detritus & $\begin{array}{l}\text { Evaluate the efficiency of the process of breaking } \\
\text { down the organic debris by the microbenthic } \\
\text { community }\end{array}$ & $\begin{array}{l}\text { The bacterial and fungal decomposition becomes } \\
\text { more prevalent, which give rise to a build-up of } \\
\text { pulpy fragments (or in absence of oxygen to fine } \\
\text { blackish material) }\end{array}$ \\
\hline $\begin{array}{l}14 \\
\text { (Max } \\
\text { Score: } 20 \\
\text { Min } \\
\text { Score: 1) }\end{array}$ & $\begin{array}{l}\text { Macrobenthic } \\
\text { Communities }\end{array}$ & $\begin{array}{l}\text { Appraise the existence of a well-structured, rich and } \\
\text { diversified community structure in the river bed } \\
\text { (good capacity of self-purification) }\end{array}$ & $\begin{array}{l}\text { The community of microbenthic organisms } \\
\text { constitutes the essential structure in the food web } \\
\text { of a fluvial ecosystem }\end{array}$ \\
\hline
\end{tabular}

\subsubsection{Environmental Flow Analysis}

The main desktop methods of environmental flow assessment (EFA) encompass the Tennant method of mean annual runoff (MAR) at a site (a threshold of $10 \%$ MAR is prerequisite for aquatic ecosystem), the range of variability approach with 32 hydrological parameters, flow duration curve (FDC) (environmental flow referred to 95 percentiles on the FDC), and desktop reserve model (measuring level of ecological protection and scoring system) (Smakhtin and Anputhas, 2006). In this study, FDC is selected to design the environmental flow in the Damodar which has extreme low flows during lean period (December to May), and the ecosystem manages with the severity of flow from high to low flows very well. The method of FDC is adapted from the works of Verma et al. (2015 and 2017), and Mitra and Singh (2018). FDC is a graphical representation of the observed historical variation of stream flows with different time resolutions, viz., daily, weekly, monthly and seasonal at the site that show the percent of time specified discharges will be equaled or exceeded over different time scales of interest (Verma et al., 2017). Two main approaches of FDC are applied here: (a) the period of record FDC by inserting cumulative density function of different 1-, 7-, 30-, 60-day time series data, unique ranking number $m$ to each flow (total $n$ ) and corresponding probability $\mathrm{P}$ of exceeding individual $i\left(\mathrm{P}_{i}=m 100 / n+1\right)$ in log-normal plot; and (b) stochastic FDC is used using daily discharge or every 5\% probability of exceedance, estimating FDC of return period 1-, 2-, 5-. 10-, 20-, 50- and 100-year and estimating probability value of exceedance equal to 95\% (Q95) (Verma et al., 2015 and 2017).

\section{Results}

\subsection{Analyzing River Metamorphosis}


It is expected that the alluvial river, Damodar, exists as a continuum state of inter-linked processes of physical and biological components at variable time-scale frame on the transfers (longitudinal, lateral and vertical distribution) of energy, material and biota, but the anthropogenic intervention (like dam) can break the state of continuum for a certain period, promoting disruption mainly in longitudinal connectivity (Casado, 2013). Schumm (1969) elucidated the fluvial metamorphosis in response to disruption in the equilibrium of fluvial hydrosystem. River metamorphosis can be referred as the expectable transformation or alternation of channel patterns, floodplain landforms, annual discharge variability, sediment type and load due to either anthropogenic activities or past climatic changes (Schumm, 1985; Miller and Miller, 2007). Schumm (1985) also explained that fluvial metamorphosis can be attributed to sediment and water detention in the reservoirs and it can change three elements of the river: (a) ability of sediment transport to downstream, (b) sediment amount available to transport and (c) quality of running water (Casado, 2013). In this case the impressive works of Brandt (2000), Graff (2005) and Petts and Gurnell (2005) provide an exhaustive information on the upstream and downstream effects of river impoundment. Taking reference to dam-controlled Damodar River it is expected more than one possibility of metamorphosis in the alluvial river: (a) change of straight channel to become sinuous or braided, (2) change of braided channel to become straight or meandering, and (3) change of meandering channel to become straight or braided. The assessment is performed here to know the present condition of metamorphosis observed in the Damodar River, mainly controlled by the Durgapur Barrage reservoir.

Table 3

Quantitative estimation of important channel dimensions and hydrologic parameters

\begin{tabular}{|c|c|c|c|c|c|c|c|c|c|c|c|c|c|c|}
\hline $\begin{array}{l}\text { Channel } \\
\text { Section }\end{array}$ & $\begin{array}{l}\text { Cumulative } \\
\text { Distance } \\
(\mathrm{km})\end{array}$ & $\begin{array}{l}D_{\max } \\
(m)\end{array}$ & $\begin{array}{l}D_{\text {avg }} \\
(m)\end{array}$ & $\begin{array}{l}W_{b} \\
(m)\end{array}$ & $\begin{array}{l}W_{B t} \\
(m)\end{array}$ & $\begin{array}{l}W_{f} \\
(m)\end{array}$ & $\begin{array}{l}A_{b c} \\
\left(m^{2}\right)\end{array}$ & $\mathrm{R}(\mathrm{m})$ & W/D & ER & $\begin{array}{l}V_{\max } \\
(m / s)\end{array}$ & $\begin{array}{l}V_{\min } \\
(m / s)\end{array}$ & $\begin{array}{l}Q_{\max } \\
\left(\mathrm{m}^{3} / \mathrm{s}\right)\end{array}$ & $\begin{array}{l}Q_{\min } \\
\left(\mathrm{m}^{3} / \mathrm{s}\right)\end{array}$ \\
\hline S1 & 4.50 & $\begin{array}{l}7.086- \\
7.816\end{array}$ & $\begin{array}{l}4.167 \\
-5.23\end{array}$ & $\begin{array}{l}682- \\
966\end{array}$ & $\begin{array}{l}394- \\
675\end{array}$ & $\begin{array}{l}836- \\
1408\end{array}$ & $\begin{array}{l}2835- \\
5546\end{array}$ & $\begin{array}{l}2.932 \\
-6.357\end{array}$ & $\begin{array}{l}112 \\
- \\
247\end{array}$ & $\begin{array}{l}1.225 \\
- \\
1.147\end{array}$ & $\begin{array}{l}1.416 \\
- \\
2.477\end{array}$ & $\begin{array}{l}0.687 \\
- \\
0.789\end{array}$ & $\begin{array}{l}4143- \\
13574\end{array}$ & $\begin{array}{l}207- \\
650\end{array}$ \\
\hline S2 & 9.46 & $\begin{array}{l}7.003- \\
7.567\end{array}$ & $\begin{array}{l}4.659 \\
- \\
4.984\end{array}$ & $\begin{array}{l}1008 \\
- \\
1418\end{array}$ & $\begin{array}{l}570- \\
1283\end{array}$ & $\begin{array}{l}2119 \\
- \\
2885\end{array}$ & $\begin{array}{l}3933- \\
4766\end{array}$ & $\begin{array}{l}3.910 \\
- \\
4.415\end{array}$ & $\begin{array}{l}202 \\
- \\
347\end{array}$ & $\begin{array}{l}1.420 \\
- \\
2.862\end{array}$ & $\begin{array}{l}1.767 \\
- \\
1.919\end{array}$ & $\begin{array}{l}0.587 \\
- \\
0.659\end{array}$ & $\begin{array}{l}6951- \\
12698\end{array}$ & $\begin{array}{l}382- \\
578\end{array}$ \\
\hline S3 & 14.08 & $\begin{array}{l}6.798- \\
8.308\end{array}$ & $\begin{array}{l}5.255 \\
- \\
6.346\end{array}$ & $\begin{array}{l}1584 \\
- \\
2509\end{array}$ & $\begin{array}{l}1584 \\
- \\
1826\end{array}$ & $\begin{array}{l}3096 \\
- \\
3721\end{array}$ & $\begin{array}{l}9152- \\
13787\end{array}$ & $\begin{array}{l}5.494 \\
- \\
5.775\end{array}$ & $\begin{array}{l}249 \\
- \\
358\end{array}$ & $\begin{array}{l}1.234 \\
- \\
1.718\end{array}$ & $\begin{array}{l}2.221 \\
- \\
2.296\end{array}$ & $\begin{array}{l}0.523 \\
- \\
0.702\end{array}$ & $\begin{array}{l}21014 \\
- \\
30618\end{array}$ & $\begin{array}{l}430- \\
1139\end{array}$ \\
\hline S4 & 19.21 & $\begin{array}{l}7.773- \\
9.08\end{array}$ & $\begin{array}{l}5.256 \\
- \\
6.386\end{array}$ & $\begin{array}{l}1605 \\
- \\
2756\end{array}$ & $\begin{array}{l}1525 \\
- \\
1994\end{array}$ & $\begin{array}{l}3300 \\
- \\
4283\end{array}$ & $\begin{array}{l}6980- \\
19957\end{array}$ & $\begin{array}{l}4.349 \\
- \\
7.216\end{array}$ & $\begin{array}{l}203 \\
- \\
319\end{array}$ & $\begin{array}{l}1.550 \\
- \\
2.491\end{array}$ & $\begin{array}{l}1.900 \\
- \\
2.663\end{array}$ & $\begin{array}{l}0.498 \\
- \\
0.778\end{array}$ & $\begin{array}{l}13265 \\
- \\
53155\end{array}$ & $\begin{array}{l}459- \\
1865\end{array}$ \\
\hline S5 & 25.09 & $\begin{array}{l}9.809- \\
10.568\end{array}$ & $\begin{array}{l}6.857 \\
- \\
7.773\end{array}$ & $\begin{array}{l}1979 \\
- \\
2098\end{array}$ & $\begin{array}{l}1550 \\
- \\
1621\end{array}$ & $\begin{array}{l}2380 \\
- \\
3468\end{array}$ & $\begin{array}{l}12509 \\
- \\
13992\end{array}$ & $\begin{array}{l}5.961 \\
- \\
7.068\end{array}$ & $\begin{array}{l}187 \\
- \\
213\end{array}$ & $\begin{array}{l}1.202 \\
- \\
1.654\end{array}$ & $\begin{array}{l}2.345 \\
- \\
2.627\end{array}$ & $\begin{array}{l}0.706 \\
- \\
0.912\end{array}$ & $\begin{array}{l}29332 \\
- \\
36759\end{array}$ & $\begin{array}{l}1161 \text { - } \\
2203\end{array}$ \\
\hline S6 & 30.50 & $\begin{array}{l}6.408- \\
10.059\end{array}$ & $\begin{array}{l}5.911 \\
- \\
7.502\end{array}$ & $\begin{array}{l}1241 \\
- \\
1689\end{array}$ & $\begin{array}{l}783- \\
1206\end{array}$ & $\begin{array}{l}3475 \\
- \\
3709\end{array}$ & $\begin{array}{l}5982- \\
10841\end{array}$ & $\begin{array}{l}4.820 \\
- \\
6.433\end{array}$ & $\begin{array}{l}168 \\
- \\
194\end{array}$ & $\begin{array}{l}2.191 \\
- \\
2.804\end{array}$ & $\begin{array}{l}2.316 \\
- \\
2.808\end{array}$ & $\begin{array}{l}0.780 \\
- \\
0.798\end{array}$ & $\begin{array}{l}13857 \\
- \\
30445\end{array}$ & $\begin{array}{l}647- \\
988\end{array}$ \\
\hline S7 & 35.96 & $\begin{array}{l}10.124 \\
- \\
11.762\end{array}$ & $\begin{array}{l}5.981 \\
- \\
6.125\end{array}$ & $\begin{array}{l}1095 \\
- \\
1903\end{array}$ & $\begin{array}{l}800- \\
1402\end{array}$ & $\begin{array}{l}3135 \\
- \\
4806\end{array}$ & $\begin{array}{l}5674- \\
10121\end{array}$ & $\begin{array}{l}5.181 \\
- \\
5.318\end{array}$ & $\begin{array}{l}93- \\
188\end{array}$ & $\begin{array}{l}2.525 \\
- \\
2.860\end{array}$ & $\begin{array}{l}2.431 \\
- \\
2.474\end{array}$ & $\begin{array}{l}0.815 \\
- \\
0.870\end{array}$ & $\begin{array}{l}13795 \\
- \\
25038\end{array}$ & $\begin{array}{l}687- \\
1445\end{array}$ \\
\hline S8 & 41.07 & $\begin{array}{l}10.202 \\
- \\
10.948\end{array}$ & $\begin{array}{l}6.220 \\
- \\
6.411\end{array}$ & $\begin{array}{l}1528 \\
- \\
1892\end{array}$ & $\begin{array}{l}1500 \\
- \\
1528\end{array}$ & $\begin{array}{l}3065 \\
- \\
3759\end{array}$ & $\begin{array}{l}10551 \\
- \\
10875\end{array}$ & $\begin{array}{l}5.658 \\
- \\
5.745\end{array}$ & $\begin{array}{l}173 \\
- \\
183\end{array}$ & $\begin{array}{l}1.642 \\
- \\
1.989\end{array}$ & $\begin{array}{l}2.578 \\
- \\
2.604\end{array}$ & $\begin{array}{l}0.746 \\
- \\
0.817\end{array}$ & $\begin{array}{l}27201 \\
- \\
28234\end{array}$ & $\begin{array}{l}1024 \text { - } \\
1309\end{array}$ \\
\hline S9 & 47.00 & $\begin{array}{l}7.520- \\
11.938\end{array}$ & $\begin{array}{l}4.976 \\
- \\
5.722\end{array}$ & $\begin{array}{l}1524 \\
- \\
2718\end{array}$ & $\begin{array}{l}1291 \\
- \\
1858\end{array}$ & $\begin{array}{l}3955 \\
- \\
4418\end{array}$ & $\begin{array}{l}7005- \\
13091\end{array}$ & $\begin{array}{l}4.594 \\
- \\
6.572\end{array}$ & $\begin{array}{l}203 \\
- \\
228\end{array}$ & $\begin{array}{l}1.627 \\
- \\
2.594\end{array}$ & $\begin{array}{l}2.244 \\
- \\
2.315\end{array}$ & $\begin{array}{l}0.771 \\
- \\
0.789\end{array}$ & $\begin{array}{l}15717 \\
- \\
30315\end{array}$ & $\begin{array}{l}1012- \\
1431\end{array}$ \\
\hline
\end{tabular}

\subsubsection{Changes in Channel Morphology}

The analysis of channel dimension results (Table 3) reveals that the upstream part of Damodar reflects relatively high in-channel sedimentation, developing numerous mid-channel and point bars and islands (figure 3). The value of $D_{\max }$ increases from $7.070 \mathrm{~m}$ to $10.568 \mathrm{~m}$ at the Barrage, and it escalates downstream up to $11.938 \mathrm{~m}$ which may be attributed to fluvial incision of low sediment load peak discharge from the Barrage. The mean channel gradient (s) of upstream section is $0.0318 \%$ and it escalates to $0.0412 \%$ at downstream section. The flood-prone width $\left(\mathrm{W}_{\mathrm{f}}\right.$ ) of Damodar River is quite low at upstream reaches (836 to $4283 \mathrm{~m}$ ), but downstream $\mathrm{W}_{\mathrm{f}}$ ranges in between 3135 and $4806 \mathrm{~m}$, showing wider river oscillation within wider floodplains. The width-depth ratio (W/D), by Rosgen (1994), isdefined as the ratio of $W_{f}$ to the maximum channel depth of the bankfull stage $\left(D_{\text {max }}\right)$. The W/D is key parameter to realize the distribution of available kinetic energy within an alluvial channel, and the ability 
of various discharges occurring within the channel to move sediments. High W/D indicates broad valley with fluvial terraces, abundance of sediment supply, slightly entrenched channel, and active lateral adjustment. W/D varies from 300 (upstream) to below 150 (downstream), and it signifies high bankfull width compare to channel depth at upstream sections due to impoundment of the Barrage (Table 3 ).

Entrenchment is the vertical containment of a river to understand the tendency of valley incision within the wider floodplain (like entrenched meander) (Rosgen, 1994). In general, high entrenchment has negative impacts (observed in study area), viz., accelerated bank erosion, land loss, loss of aquatic habitat, loss of land productivity, lowering of water table and sedimentation of the river downstream. The entrenchment ratio (ER), by Rosgen (1994), is the ratio of flood-prone width to the surface width of the bankfull channel (measured at twice the maximum depth of bankfull channel). It is observed from the Sentinal 2A image (2021) that at upstream of the Barrage ER varies widely from 1.202 to 2.862 (mean 1.650 ) which signifies highly to moderately entrenched channel in a well-developed floodplain. Significantly, the river turns into slightly entrenched channel below the Barrage because the value varies from 1.810 to 2.497 (mean 2.275). Surprisinglythe river sinuosity does not vary too much in the study area, i.e., SI (Friend and Sinha,1993) range of 1.036 to 1.135 (more tend to straight channel). The strong linearity of Damodar may be attributed to two factors: (a) the river follows a W-E lineament of the Bengal Basin crossing three prominent basement faults (viz., Chhotanagpur Foothill Fault, Khandaghosh-Garhmayna Fault and Pingla Fault), and (b) the dam-controlled river is jacketing by elevated embankments at both banks to stop oscillation in the floodplain (i.e., anthropogenic confinement). Braiding nature of the river reflects a threshold level of sediment load or slope to maintain a steep gradient throughout the long profile. High tendency of braiding means abundant supply of sediments from upstream, flow blockage by dam impoundment, in-channel sedimentation (low flushing due to damming), rapid and infrequent discharge. The braid-channel ratio (BR), by Friend and Sinha (1993), reflects a typical pattern in the Damodar valley. BR is estimated as 2.173 at the initial survey section (S1) and it escalates up to 4.316 at the Durgapur Barrage section (S5) due to development morelinguoid bars and islands. Below the Barrage, BR drops to 1.811 up to $10 \mathrm{~km}$ stretch, and after that it again increases up to 3.525 . The main reason is the fluvial incision and channel narrowing at just downstream of Barrage, and further the eroded sediments are deposited in downstream channel.

\subsubsection{Changes in Channel Carrying Capacity and Flow Regime}

The bankfull cross-sectional area $\left(A_{b c}\right)$ (assuming channel geometry as trapezoid form), mass flow rate and bankfull discharge are estimated using DEM and MIKE 21 hydrological software in nine reach sections (taking five cross-section samples from each reach). The parameter $A_{b c}$ is estimated at bankfull stage to get an idea of flood discharge variability at maximum level $\left(Q_{\max }\right)$. At upstream of the Barrage the value of $A_{b c}$ varies highly from 2,835 to $19,957 \mathrm{~m}^{2}$ (mean 9,345 $\mathrm{m}^{2}$ ), and at downstream the value ranges in between 5,674 and 13,091 $\mathrm{m}^{2}\left(\mathrm{mean} 9267 \mathrm{~m}^{2}\right.$ ). The manning's roughness coefficient $\left(n_{c}\right)$ of lower Damodar River is estimated as 0.025 to 0.035 by Singh et al. (2020). The estimated $Q_{m a x}(i . e$. , potential bankfull discharge) varies widely from 4,143 to $53,155 \mathrm{~m}^{3} \mathrm{~s}^{-1}$ in the upstream reaches of Damodar (having average hydraulic radius of 2.932 to $7.216 \mathrm{~m}$ ). Below the Barrage it ranges from 13,795 to $30,445 \mathrm{~m}^{3} \mathrm{~s}^{-1}$ (having average hydraulic radius of 4.820 to $6.572 \mathrm{~m}$ ). In general, there is a reduction of bankfull carrying capacity of channel (below the Barrage) to accommodate maximum flood flow during monsoon due to channel narrowing and terrace formation within the valley. It is observed that the minimum flow rate (during lean season) varies from 528 to 1287 $\mathrm{m}^{3} \mathrm{~s}^{-1}$ at upstream reaches, but due to flow regulation it maintains in between 842 and $1293 \mathrm{~m}^{3} \mathrm{~s}^{-1}$ up to the Rhondia weir. It signifies relatively good environmental flow which is the minimum flow required for the sustainable maintenance of riparian and aquatic ecosystem. The studies of Ghosh (2011), Bhattacharyya (2011), Ghosh and Guchhait (2016), Verma et al. (2017), and Karim and De (2019) revealed that four primary types of flow regulation were observed in the Damodar River, viz., (1) peak absorption (peak flows from catchment tributaries absorbed in reservoirs), (2) peak attenuation (reduced or delayed due to reservoir attenuation), (3) release manipulation (dam designed for flood control keeping reservoir volume as low), and (4) maintenance of environmental flow (3.4 to $31.48 \mathrm{~m}^{3} \mathrm{~s}^{-1}$ ) during lean period. After construction of the DVC dams and Durgapur Barrage reservoir (built before 70 years) the flow discharge is variable and reduced significantly, i.e., reduction of mean annual peak flow from 8,378 to 3,522 $\mathrm{m}^{3} \mathrm{~s}^{-1}$ at Rhondia weir. Before dam construction the confidence limit of annual peak discharge was recorded between 6,081 and $10,676 \mathrm{~m}^{3} \mathrm{~s}^{-1}$, but after 1958 the limit reduced to only 2,574-4,470m $\mathrm{s}^{-1}$ (Ghosh and Guchhait, 2016).

\subsubsection{Problem of In-channel Sedimentation and Reservoir Sedimentation}

The turbidity and sediment concentration of the downstream channel flow are reduced due to sediment isolation in the DVC reservoirs, and the grain size reduction is inevitable in the delivered sediments (e.g., sediment coarsening at upstream of dam and sediment fining at downstream of dam). Clear water releases have an unfilled capacity to transport sediments (hungry water), which increases their erosive power regardless of the potential reduction of the effective flow (Casado, 2013). Bed degradation is usually the most immediate channel adjustment after dam closure, although bed aggradation processes and bank stabilization by vegetation encroachment have been also widely documented (Casado, 2013). Two prominent effects of the Barrage are recognized: (1) at downstream the river becomes more narrower due to incision of sediment free peak flow, and (2) at upstream the sediments are trapped in the channel to decrease the cross-sectional area and to increase the river width. The floodplain width is estimated near about 2 - 3km wide at downstream, but the active channel width is reduced to only $510-1110 \mathrm{~m}$ at present (up to $14 \mathrm{~km}$ downstream stretch from the Barrage). The previous oscillation of active channel is compressed by the flow regulation of barrage, embankment rise and encroachment of river islands for agriculture and settlement. The upstream section is controlled by the Barrage flow obstruction and urban-industrial complex. The trapped sediments and low flow competence increase the number and size of longitudinal bars in the channel up to 17 km upstream. These elevated islands (locally known as 'manas') are now used for the settlements and agricultural practices. The in-channel

Page 9/28 
sedimentation is reflected from the increasing value of BR (i.e., 2.173 to 4.316; tending more to braided channel), and this morphological change reduces the in-channel carrying capacity to accommodate the peak flood flow during monsoonal period.

More than half of sediments from the controlled river basins are trapped by dams and about 25.30 percent of sediments worldwide are intercepted by large dams (Bhattacharyya, 2011). It is inevitable that due to unscientific coal mining, urbanization, extensive deforestation, soil erosion and expansion of agriculture in the Chhotanagpur Plateau the Damodar River transported an enormous sand load during floods and the bars are formed. The suspended sediment concentration was measured at Damodar Bridge site ( $29 \mathrm{~km}$ downstream of Panchet dam), and the value decreased from $1.87 \mathrm{gm} \mathrm{l}^{-1}$ (pre-dam) to $0.54 \mathrm{gm} \mathrm{l}^{-1}$ (post-dam), promoting almost 72 percent reduction of sediment concentration in channel flow (Bhattacharyya, 2011). The data reveals that the Maithon reservoir of Barakar River lost about 27.4 percent of overall storage capacity up to 2001, whereas the Panchet reservoir of Damodar River lost 15.9 percent of overall storage capacity (WRIS, 2021). In the Matithonreservior the

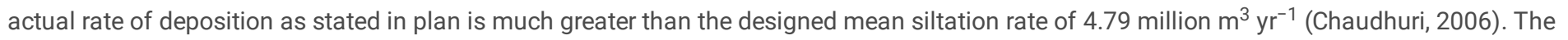
siltation rate at the Maithon Reservoir will be reduced to about 1.5 million $\mathrm{m}^{3} \mathrm{yr}^{-1}$ due to installation of another dam on the Barakar River, Balpaharidam (at $50 \mathrm{~km}$ upstream of Maithon) (Chaudhuri, 2006). The estimated siltation rate of DVC reservoirs is depicted as follows (Table 4): (1) Konar - 1.743 million $\mathrm{m}^{3} \mathrm{yr}^{-1}$, (2) Maithon - 6.77 million $\mathrm{m}^{3} \mathrm{yr}^{-1}$, (3) Panchet - 6.92million $\mathrm{m}^{3} \mathrm{yr}^{-1}$, (4) Tenughat - $3.210 \mathrm{million} \mathrm{m}^{3} \mathrm{yr}^{-1}$, and (5) Tilaiya -2.748 million $\mathrm{m}^{3} \mathrm{yr}^{-1}$ respectively (Bhattacharyya and Singh, 2019). The reduction of gross storage varies from $11.85 \mathrm{million}^{3}$ (1955) to 6.437 million $\mathrm{m}^{3}$ in the Durgapur Barrage reservoir, reflecting 45.68 loss of live storage. At present the average rate of siltation is 0.042 million $\mathrm{m}^{3} \mathrm{yr}^{-1}$ in the Barrage (WRIS, 2021).

Table 4

Rate of sedimentation in the DVC reservoirs and Durgapur Barrage reservoir

\begin{tabular}{|c|c|c|c|c|c|c|}
\hline \multirow{2}{*}{$\begin{array}{l}\text { SI } \\
\text { no }\end{array}$} & \multirow{2}{*}{$\begin{array}{l}\text { Name of } \\
\text { Reservoir }\end{array}$} & \multirow{2}{*}{$\begin{array}{l}\text { Name of } \\
\text { River }\end{array}$} & \multirow{2}{*}{$\begin{array}{l}\text { Total Years (year of built \& year of last } \\
\text { survey) }\end{array}$} & \multicolumn{3}{|c|}{ Rate of sedimentation } \\
\hline & & & & $\begin{array}{l}\mathrm{M} \mathrm{m}^{3} \\
\mathrm{yr}^{-1}\end{array}$ & $\begin{array}{l}\mathrm{m}^{3} \mathrm{~km}^{-2} \\
\mathrm{yr}^{-1}\end{array}$ & $\begin{array}{l}\text { ha } \mathrm{m} / 100 \mathrm{~km}^{2} \\
\mathrm{yr}^{-1}\end{array}$ \\
\hline 1 & Konar & Konar & $41(1955-1996)$ & 1.743 & 1748 & 17.48 \\
\hline 2 & Maithon & Barakar & $39(1955$ - 1994) & 6.77 & 1076 & 10.76 \\
\hline 3 & Panchet & Damodar & $56(1956-2012)$ & 6.92 & 631 & 6.31 \\
\hline 4 & Tenughat & Damodar & $31(1970-2001)$ & 3.21 & 716 & 7.16 \\
\hline 5 & Tilaiya & Barakar & $44(1953-1997)$ & 2.748 & 2792 & 27.92 \\
\hline 6 & Durgapur Barrage & Damodar & $56(1955-2011)$ & 0.042 & - & - \\
\hline
\end{tabular}

\subsubsection{Characterization in River Metamorphosis}

The pertinent hydrogeomorphic research works of Ghosh (2011), Bhattacharyya (2011), Ghosh (2011), Ghosh and Guchhait (2014 and 2016), Pal et al. (2015), Verma et al. (2017), and Karim and De (2019) have revealed that river ability to transport, sediment available to transport and quality of running water simultaneously trigger a series of adjustments until the fluvial system of Damodar either accommodates the anthropogenic disturbance or reaches a new equilibrium state. Alluvial river is a sensitive element of earth's surface, whereas any change or shift in external factors (e.g., climate change or tectonic upliftor river impoundment) it instigates a rapid response from the fluvial system towards instability (i.e., disequilibrium) within the floodplains. It is hypothesized that the Damodar River is still situated in a phase of river instability or disequilibrium which is generally considered to be that period during which river processes and form readjust to a change (changes in land uses and installation of dams since 1950s) in the sedimentologic and hydrologic regime (Miller and Miller, 2007). It can be considered this situation in a framework of threshold and complex response (Schumm, 1972) where the driving forces and resisting forces operating within the Damodar River were altered (due to dam construction and rise of embankments) to a such a degree that the limits to equilibrium were exceeded. Due to this threshold event the changing channel morphology and floodplain transformation have initiated an outlook of river metamorphosis which is depicted here as follows.

A threshold crossing event, viz., multipurpose large dam construction by DVC, occurred when the river system moved from a state of natural balance to a temporary condition of disequilibrium which is now gradually corrected as the system develops a new sate of balance adjusted to a different set of environmental conditions. After crossing the threshold, the alteration in channel forms and patterns (complex response) was initially rapid and decreases with time until a new equilibrium state is achieved, because the large dams can change the local base level conditions, forming several knickpoints in longitudinal profile. 
Base level change promotes incision to a certain distance downstream, but the aggradation dominates further to develop terraces and bars. It is predicted that within 100 years of time frame the changes in lithology of sand-bed channels, bed configuration, cross-sectional form (width-depth ratio), braiding or sinuosity and channel confinement are more evident. Within 100 to $10^{4}$ years of time frame the change of meander wavelength, channel gradient, and profile concavity can be traced. Two prominent metamorphosis scenarios are observed in the Damodar River: (1) Downstream of Barrage - significant reduction of flow competence $\left(\mathrm{Q}^{--}\right)$and sediment load $\left(\mathrm{L}^{-}\right)$, dominance of fluvial incision $\left(\mathrm{I}^{+}\right)$over aggradation and terrace formation, increase of slope $\left(\mathrm{s}^{+}\right)$, increase in depth $\left(\mathrm{d}^{+}\right)$, decrease in active channel width ( $\left.\mathrm{w}^{-}\right)$, and overall significant reduction in channel capacity $\left(\mathrm{CC}^{--}\right)$; and (2) Upstream of Barrage- moderate reduction of flow competence $\left(\mathrm{Q}^{-}\right)$and unchanging sediment load $\left(\mathrm{L}^{\circ}\right)$, dominance of fluvial aggradation over incision $\left(\mathrm{I}^{-}\right)$and longitudinal bar formation, decrease of slope $\left(\mathrm{s}^{-}\right)$, decrease in depth $\left(\mathrm{d}^{-}\right)$, increase in active channel width $\left(\mathrm{w}^{+}\right)$, and overall moderate reduction in channel capacity $\left(\mathrm{CC}^{-}\right)$.

Based on the geomorphic characterization (Level I) and morphological description (Level II) the reaches of Damodar River can classified through Rosgen stream classification scheme (Rosgen, 1994). The key parameters of Level I (e.g., channel slope, channel shape and channel pattern etc.) and Level II (e.g., entrenchment ratio, width-depth ratio, sinuosity index, channel materials etc.) are presented in table. Similarly, the floodplain classification scheme of Nanson and Croke (1992) is applied to know the floodplain metamorphosis in relation to river impoundment. At upstream of the Durgapur Barrage the channel has transformed to A type to B and then, $D$ type. After crossing the Barrage, the channel has reversed into again $B$ type, and further downstream it changes to again D type. A type channel has attributes of steep-entrenched channel with high energy/debris transport with erosional or depositional and Gondwana bedrock forms. B type channel is characterized as moderately entrenched, riffle dominated channel, stable banks and point bars, gently sloping valley with occasional pools. D type channel is slightly entrenched with braided pattern, longitudinal and transverse bars, very wide channel with multiple threads, active lateral adjustment, and abundance of sediment supply. In case of floodplain classification, two sequences are observed as follow: (a) Change from A3 to B1 type at upstream, and (b) again change from A3 to B1 type at downstream. A3 type floodplain is characterized by unconfined to confined vertical accretion, specific stream of 300 - $600 \mathrm{Wm}^{-2}$, sandy-strata with inter-bedded muds, sandy flat floodplain surface with single-thread channel wandering, occasional channel wandering, overbank vertical accretion, island deposition, and abandoned channel accretion with minor lateral accretion. B1 type floodplain is categorized as usually braided channel, specific stream of $50-300 \mathrm{Wm}^{-2}$, floodplains with gravels, sand and silts in bed sediments, braidedchannel accretion and incision, overbank vertical accretion of islands and abandoned channel accretion, undulating floodplain of abandoned channels and bars, backswamps and relatively high sediment load. So, it can be said that the Durgapur Barrage reservoir has controlled the floodplain associations and characteristics of the Damodar River, changing braided nature (mainly upstream of barrage) to single thread entrenched channel.

Table 5

Brief summary of channel and floodplain classification criteria

\begin{tabular}{|c|c|c|c|c|c|c|c|c|}
\hline $\begin{array}{l}\text { Channel } \\
\text { Section }\end{array}$ & $\begin{array}{l}\text { Cumulative Distance } \\
(\mathrm{km})\end{array}$ & SI & BR & ER & W/D & Mean Channel Slope (\%) & $\begin{array}{l}\text { Channel } \\
\text { Type }^{1}\end{array}$ & $\begin{array}{l}\text { Floodplain } \\
\text { Type }^{2}\end{array}$ \\
\hline S1 & 4.50 & 1.09 & 2.17 & 1.19 & 179 & \multirow[t]{5}{*}{0.0318 (Upstream of Barrage) } & $A$ & \multirow[t]{3}{*}{ A3 } \\
\hline S2 & 9.46 & 1.04 & 2.2 & 2.14 & 274 & & B & \\
\hline S3 & 14.08 & 1.08 & 2.72 & 1.48 & 303 & & B & \\
\hline S4 & 19.21 & 1.05 & 3.21 & 2.02 & 261 & & D & \multirow[t]{2}{*}{ B1 } \\
\hline S5 & 25.09 & 1.04 & 4.32 & 1.43 & 200 & & D & \\
\hline S6 & 30.50 & 1.12 & 1.96 & 2.5 & 181 & \multirow{4}{*}{$\begin{array}{l}0.0412 \text { (Downstream of Barrage up to } \\
\text { Rhondia Weir) }\end{array}$} & B & \multirow[t]{2}{*}{ A3 } \\
\hline S7 & 35.96 & 1.07 & 1.81 & 2.69 & 140 & & $B$ & \\
\hline S8 & 41.07 & 1.1 & 2.52 & 1.81 & 178 & & $D$ & \multirow[t]{2}{*}{ B1 } \\
\hline S9 & 47.00 & 1.14 & 3.53 & 2.11 & 215 & & D & \\
\hline
\end{tabular}

Note: Entrenchment ratio - ER; sinuosity index - Sl; braid-channel ratio - BR; channel width-depth ratio -W/D; 1 - Rosgen stream classification system; 2 - Nanson and Croke floodplain classification system

\subsection{Evaluating Fluvial Functionality}

The developed thematic FFI map of Damodar River (figure 8) enables the present status of functioning (individual stretch) to be grasped straightway and it can be a useful instrument for planning the reclamation of the fluvial environment. Based on the FFI evaluation, the Damodar River functionality level varies from category IV to II, i.e., poor to good-fair functionality level. The FFI score varies from 85 to 181 , showing prominent influence of transverse obstacles, eutrophication, anthropogenic bed modifications and urban-industrial pollutants. Only, S2 section shows good-fair fluvial functionality level II, showing relatively abundance of flora and fauna, morphological diversity of river bed, proliferation of 
complex formation and riparian vegetation (strip greater than $30 \mathrm{~m}$ ). The key problem is observed in the river stretch immediate upstream and downstream of the Durgapur Barrage reservoir, yielding very low FFI score of 61 - 100 (category IV poor functionality level). The observed factors of this low fluvial functionality are mainly categorized as follows: (a) daily influx of sewage and industrial pollutant water from Durgapur - Waria

- Raniganj townships, thermal power plant and heavy industries; (b) intensive agriculture in stabilized islands; (c) flow obstacles by the Barrage sluices and linear transverse construction; (d) sand mining with heavy machines and vehicles; and (e) issue of reservoir siltation and in-channel sedimentation (figure 9). At downstream of the Barrage, the river recovers its functionality to category III level (i.e., fair), but the complex formation and riparian structure are not proliferated in the sand dominated alluvial valley mainly due to channel narrowing, discharge variability (environmental flow), and intensive in-channel sand mining and agricultural practices. The main aquatic vegetation communities of the Barrage reservoir and river bed are identified as Eichhorniacrassipes, Salviniacuculata, Nelumbonucifera, Hydrillaverticillata, Ipomoea aquatic, LemnaSp, Typhaspetc. (Gupta and Mukherjee, 2015). The dominant floral species of sandy river bed is Saccharumspontaneum which grows highly during monsoon period. The surroundings of the Barrage are now identified as Important Bird and Biodiversity Area (IBA) (figure 9) by the Birdlife International (Cambridge, United Kingdom), having record of 253 species (Adhurya et al, 2015).

From the survey and FFI report card analysis, the key issues (need for restoration or management) of this fluvial ecosystem are recognized as follows (figure 9): (a) seasonal cultivation with expansion of urban areas mainly in the left bank floodplain; (b) absence of riparian formations but presence of anyway functional formations due to mobile river bed and bed modifications frequent interruption and loss of continuum state); (c) frequent flow disturbances with the lean flow of six dry months; (d) flood stage river breadth occasionally overcomes greater than 2 to 3 times of the moderate flow river bed; (e) absence of retention structure that enhancing reed groves and hydrophytes; (f) artificial intervention escalates very low morphological diversity and bed stabilization in the river cross-sections; (g) intensive sand mining and allied activities become a threat to avian wildlife of the Damodar River; and (h) very low density of tolerating riparian plant component, recognizable fibrous - pulpy detritus materials. The zone - in yellow (S1, S7, S8 and S9) - needs to restore the eco-buffer in the peri fluvial zone, taking measures to restrict the expansion of commercial activities and residential use. The zone - in orange (S3 to S6) - needs more precaution from intense urbanization and decreasing ecological diversity through limiting the intervention and boosting up ecological quality. The results of the FFI at the reach level of dam-controlled Damodar River provide us the possibility to do more research at the micro-level to mitigate the impact or to reassess the quality of the fluvial environment in the era of Anthropocene. There is a need for a fluvial zone of adequate ecological quality, made up of well-established arboreal and shrubby riparian formations (act as eco-buffer to surrounding territory), that must be protected and correctly maintained in the Damodar River.

\subsection{Flow Alterantion and Fluvial Functionality}

The flow duration curve is used to assess environmental flows to illustrate the hydrological situation of the river system(Suwal et al. 2020). It represents the proportion flow exceeded to the percentage of time at a particular river section. This exceedance curve is used to define a minimum threshold value for sustaining and maintaining the riverine ecological integrity. This flow duration (Fig. 11a,b) curve has been constructed based on the average monthly flow discharge data of the lean period (December to May) at Rhondia of Damodar River in the pre-dam (1934-1957) and post-dam period (1958-1957). Based on the flow duration curve, it reveals that $97.8 \%$ exceedance probability is attained and it's the corresponding flow value is $1 \mathrm{~m}^{3} / \mathrm{s}$ in the pre-dam period. Therefore, $1 \mathrm{~m}^{3} / \mathrm{s}$ flow was available throughout the months of the lean period in the pre-dam period. Whereas $98.8 \%$ exceedance probability is attained in the post-dam period and its corresponding flow value is $8 \mathrm{~m}^{3} / \mathrm{s}$ of flow. Hence $8 \mathrm{~m}^{3} / \mathrm{s}$ flow is available throughout the months of the lean period in the post-dam period. So, the exceedance probability with its corresponding flow value slightly increases (from 1 to $8 \mathrm{~m}^{3} / \mathrm{s}$ ) after the construction of dams and barrage. 
Table 6

Frequency analyses of daily average flow at Rhondia site of Damodar River in preand post-dam periods

\begin{tabular}{|c|c|c|c|c|}
\hline \multicolumn{4}{|c|}{ Daily average flow } & \multirow[t]{2}{*}{ Return time } \\
\hline EF & Predam (1940-1950) & Post-dam (1993-2008) & change & \\
\hline$\%$ & $\left(\mathrm{~m}^{3} / \mathrm{s}\right)$ & $\left(\mathrm{m}^{3} / \mathrm{s}\right)$ & $\left(\mathrm{m}^{3} / \mathrm{s}\right)$ & (years) \\
\hline 1 & 3575 & 2460 & -1115 & 100 \\
\hline 5 & 1977 & 1139 & -838 & 20 \\
\hline 10 & 1263 & 681 & -582 & 10 \\
\hline 20 & 577 & 322 & -255 & 5 \\
\hline 30 & 200 & 168 & -32 & 3.33 \\
\hline 40 & 85 & 99 & 14 & 2.50 \\
\hline 50 & 38 & 66 & 28 & 2.00 \\
\hline 60 & 19 & 37 & 18 & 1.67 \\
\hline 70 & 9 & 16 & 7 & 1.43 \\
\hline 80 & 3 & 6 & 3 & 1.25 \\
\hline 85 & 0.7 & 2 & 1.3 & 1.18 \\
\hline
\end{tabular}

The daily average flow at Rhondia site of Damodar River in the pre-dam (1940-1950) and post-dam (1993-2008) periods has been analyzed to evaluate the environmental flow for the recommendation of daily flow for the aquatic environment. Based on this analysis, the flow discharge corresponding to $85 \%$ exceedance probability is 0.7 and $2 \mathrm{~m}^{3} / \mathrm{s}$ of flow in the pre and post-dam periods respectively. Whereas, $1 \%$ exceedance probability to its corresponding flow is 3575 and $2460 \mathrm{~m}^{3} / \mathrm{s}$ in the pre and post-dam periods respectively. The corresponding flow of $1,5,10,20$, and $30 \%$ exceedance probability reduces which means the probability of daily high flow has been decreased. While $40,50,60,70,80$, and $85 \%$ exceedance probability to its corresponding flow increases that means the probability of daily low flow has been increased after the installation of dams and barrage. So, the variability of daily flow has changed due to the regulation of flow by dams and barrages.

This flow duration (Fig. 12) curve has been constructed based on the daily average flow discharge data at Rhondia of Damodar River in the predam (1940-1950) and post-dam period (1993-2008). According to the reference flow duration curve, any shift of an FDC to the left means this loss (part of variability is lost) due to the reduced assurance of monthly flows, i.e. same flow will be occurring less frequently. The corresponding flow of $1,5,10,20$, and $30 \%$ exceedance probability reduces due to the flow regulation and the flow occurs less frequently. Whereas the corresponding flow of $40,50,60,70,80$, and $85 \%$ exceedance probability increases and flow occurs in high frequency. The flow duration curve of high-frequency flow (<30\% exceedance probability of flows) shifts left and the lower frequency flow ( $>40 \%$ exceedance probability of flows) curve shifts right after the construction of dams and barrage on Damodar River (Fig. 12). Hence, the analysis of the daily flow and flow duration curve indicates that the variability is lost due to reducing high flows frequency and increasing lows flow frequency in the river. So, the variability of daily flow has changed due to the regulation of flow by dams and barrages. 
Table 7

Environmental flow assessment through Tennant method

\begin{tabular}{|c|c|c|c|c|c|c|}
\hline \multirow[t]{2}{*}{ Months } & \multicolumn{3}{|c|}{ Pre-dam (1934-1957) } & \multicolumn{3}{|c|}{ Post-dam (1958-2007) } \\
\hline & $\begin{array}{l}\text { Average monthly } \\
\text { discharge in } \mathrm{m} 3 / \mathrm{s}\end{array}$ & $\begin{array}{l}\text { MAF in } \\
\mathrm{m} 3 / \mathrm{s}\end{array}$ & $\begin{array}{l}\text { Minimum flow for Aquatic- } \\
\text { Habitat (10\% MAR) }\end{array}$ & $\begin{array}{l}\text { Average monthly } \\
\text { discharge in } \mathrm{m} 3 / \mathrm{s}\end{array}$ & $\begin{array}{l}\text { MAF } \\
\text { in } \\
\text { m3/s }\end{array}$ & $\begin{array}{l}\text { Minimum flow for Aquatic- } \\
\text { Habitat (10\% MAR) }\end{array}$ \\
\hline $\begin{array}{l}\text { (Mar- } \\
\text { May) }\end{array}$ & 57.05 & \multirow[t]{4}{*}{1001.33} & \multirow[t]{4}{*}{100.13} & 103.83 & \multirow[t]{4}{*}{700.04} & \multirow[t]{4}{*}{70} \\
\hline $\begin{array}{l}\text { (Jun- } \\
\text { Sept) }\end{array}$ & 3371.18 & & & 2145.86 & & \\
\hline $\begin{array}{l}\text { (Oct- } \\
\text { Nov) }\end{array}$ & 477.05 & & & 433.48 & & \\
\hline $\begin{array}{l}(\mathrm{Dec}- \\
\text { Feb) }\end{array}$ & 100.05 & & & 117.00 & & \\
\hline
\end{tabular}

The concept of environmental flow suggests that a minimum flow is required to maintain and sustain the riverine ecosystem and ecology. According to the Tennat method, a minimum (i.e.10\% of MAF) percentage of the mean annual flow (AAF) is a prerequisite for aquatic habitat to maintain the biological integrity of the riverine ecosystem. The mean annual flow (MAF) of the pre-dam period was $1001.33 \mathrm{~m} 3 / \mathrm{s}$ but due to flow regulation, it decreases $700.04 \mathrm{~m} 3 / \mathrm{s}$ in the post-dam period at Rhondia site of the Lower Damodar River. The requirement of minimum flow for riverine habitat was $100.13 \mathrm{~m} 3 / \mathrm{s}$ in the pre-dam period while it is $70 \mathrm{~m} 3 / \mathrm{s}$ in the post-dam period. As the flow is regulated to maintain the minimum flow in the river system, the requirement of minimum flow for aquatic habitat is also decreasing due to reduced MAF. A threshold of $10 \%$ MAR for the aquatic ecosystem is not met in the lean season (December to May months) in the pre-dam period whereas it is met in the pre-dam period as per the average monthly data at Rhondia site of the Lower Damodar River.

\section{Discussion}

Most of the world's major rivers are intensively modified (Goldenberg-Vilar et al. 2021) by the water resource management tools such as dams and barrages through which have altered seasonal flow regime and peak flow discharge on a global scale. Flow discharge is a vital element that impacts significantly on the aquatic habitat, river morphology, biotic life, river connectivity, and water quality (Mitra and Singh 2018). The frequency, duration, timing, and intensity of daily, monthly, and annual peak flow have a direct impact on riverine biota (Lin 2011), but high range of variation in steam flow (Bunn and Arthington 2002) affects minimizing habitat and aquatic biodiversity (Richter \& Thomas, 2007), decreasing self-purifying ability (Dudgeon, 2000) and alteration in erosion and deposition (Verma, Murthy, \& Tiwary, 2015). The flow of the Damodar River is variable and reducing significantly after the installation of DVC dams and barrage on it (Ghosh and Mistri 2013; Bhattacharya 2011; Verma, Murthy, \& Tiwary, 2015). After the construction of dams and barrage, it reduces the mean annual peak flow from 8378 to $3522 \mathrm{~m}^{3} \mathrm{~s}^{-1}$ at Rhondia. The alteration of flow discharge impacts physical processes (sediments transportation, bank erosion), morphology, channel structure, floodplain hydrology, and biodiversity (Lin 2011; Krchnak \& Thomas, 2009). The flow alteration changes the river metamorphosis as it changes the channel pattern, flood plains landforms, annual discharge variability, sediment type, and load. The analysis of channel dimension reveals that the channel morphology has changed due to altering and diver the flow regulation by the anthropogenic intervention. The fluvial functionality and ecogeomorphological behaviour of Damodar River are largely influenced by flow discharge variability, and the destabilized fluvial functionality of the River impacts the proliferation of sustainable ecosystem fuctions and ecological behaviour in the active channel and floodplain. The anthropogenic structural interventions, like dam, barrage, embankment and weir on Damodar River, divert and alter the flow (Krchnak \& Thomas, 2009; Vucijak, Zvanut, \& Antonelli, 2015; Pal, 2015) which impacts the hydrological functionality, floodplain connectivity through palaeochannels, and siltation of barrages and channel, losing carrying capapcity during bankfull discharge. Besides, the other anthropogenic interventions such as urban-industrial waste disposal with their effluents, off the bed and on bed intensive agricultural practice with their effluents and mining activities (like sand, coal) affect the fluvial functionality of the river systems.

The FFI score indicates that the ecological functionality level of Damodar River ranges from poor to good-fair (i.e., category IV-II) functionality level due to the effects of transverse obstacles, eutrophication, anthropogenic bed modifications, urban-industrial pollutants, mining activities, flow alteration and diversion, agricultural and urban expansion. Although there is a spatial variation of ecological functionality level in nine channel sections of the study area. The ecological functionality level of the upper and immediately lower section (S3 to S6) of the Durgapur barrage is poor due to the impact of the Durgapur barrage as a fluvial response to the river impoundment, the alteration flow regime (flow variability), and the other anthropogenic interference. The minimum flow rate in the upper reach of the Durgapur barrage ranges from 528 to $1278 \mathrm{~m}^{3} \mathrm{~s}^{-1} \mathrm{while}$ it ranges from 842 and $1293 \mathrm{~m}^{3} \mathrm{~s}^{-1}$ in the down reach during the lean season as flow regulated. The alteration and reserving of peak flow through 
the reservoir reduce the sediment load downstream by tapping and filtering sediments. The upstream sections (S3 to S6) are controlled by the barrage and influenced by the urban-industrial complex. The effect of the Durgapur barrage escalates narrowing of downstream channel width due to sediment-free peak flow (more erosion), widening the upstream width, and reducing cross-sectional area due to trapping sediment in upstream channel and reservoir. By trapping sediments in the in-channel siltation reduces the mean channel gradient at upstream. The mean channel gradient of upstream is 0.0318 percent whereas it is 0.0412 percent in the downstream. Many mid-channel and point bars and islands are developed due to trapping sediments and low flow capacity. These islands and bars (locally named as 'mana') are intensively used for permanent settlements and intensive agriculture, encroaching the active part of channel and living with floods.

The ecological functionality level in the section S3 to S6 is poor and the FFI score ranges from 61 to 100 due to flow alteration, low flow capacity, intensive agriculture on the bed and urban-industrial effluents. The urban-industrial waste disposal with various intoxicants pollutants discharges into the river in this section from the industrial and urban complex of Durgapur (De et al. 1980, 1985). Moreover, the urban-industrial effluents with numerous intoxicant pollutants discharge into the river in this section through the Nala. For example, Tamla Nala (after immediate to the Durgapur barrage) and Singaran Nala (upper Durgapur barrage) constantly contaminate the river and the barrage (De et al. 1980 and 1985). The agricultural effluents with pollutants discharge directly into the river in this section as intensive agriculture practice on the mid-channel bar. The urban and agricultural (off the bed and on the bed) expansion with its increasing disposal and effluents discharge into the river leads to decrease ecological functionality level directly or indirectly in these sections.

The FFI has been applied to evaluate the ecological functionality level for the restoration of the riverine environment. It would help to restore the fluvial ecosystem and ecology which serve their benefits to humans. So, it can be used as a planning tool for the restoration or reclamation of the fluvial environment. Analysis of ecological functionality level would help to restore the degraded fluvial ecosystem, riparian flora, and fauna. The FFI can be used as a management tool for assessing the ecological structure, function, and change of river stretch.

\section{Conclusions}

Structural interventions such as dams and barrage of DVC on the Damodar river system have altered and diverted the flow regimes of this river system which has affected eco-geomorphological behaviour and fluvial functionality. Other non-structural interventions such as urban-industrial and agricultural growth in the forms of development have threatened the hydro-chemistry of the river system which has also changed the fluvial functionality of the river system. The major findings are reduced mean annual peak flow from 8378 to $3522 \mathrm{~m}^{3} \mathrm{~s}^{-1}$, increasing minimum mean monthly flow discharge in lean period (December to May) from 1 to $8 \mathrm{~m}^{3} \mathrm{~s}^{-1}$, losing of the flow variability as the frequency of high flows is reduced and low flows have increased and reduced MAF from 1001.33 to $700.04 \mathrm{~m}^{3} \mathrm{~s}^{-1}$ in the post-dam period. This radical shift in the flow regimes has been changed the channel morphology. It is observed that the maximum channel depth, mean channel gradient, flood-prone width, and width-depth ratio are decreasing in the upstream sections while they are increasing in the downstream section of the Durgapur barrage due to sedimentation in the upstream channel and reservoir. The entrenchment ratio (ER) of upstream ranges from 1.202 to 2.862 with 1.65 mean value) while it is lower than downstream (ranging from 1.810 to 2.497 with a mean value of 2.275). Although the bankfull cross-sectional area ( $A_{b c}$ ) of upstream varies from 2,835 to $19,957 \mathrm{~m}^{2}$ with a mean of 9,345 $\mathrm{m}^{2}$, it is higher than that of the downstream section (varying from 5,674 and $13,091 \mathrm{~m}^{2}$ with a mean of $9267 \mathrm{~m}^{2}$ ). The turbidity and sediment with its grain size concentration have reduced in the downstream channel while they are increasing in the downstream channel due to trapping and filtering by the reservoir. Now the average rate of siltation is 0.042 million $\mathrm{m}^{3}$ $\mathrm{yr}^{-1}$ in the Barrage.

The changing channel morphology and floodplain transformation have initiated and two prominent metamorphosis scenarios are observed in the Damodar River: (1) Downstream of Barrage - significant reduction of flow competence $\left(\mathrm{Q}^{--}\right)$and sediment load $\left(\mathrm{L}^{-}\right)$, dominance of fluvial incision $\left(\mathrm{I}^{+}\right)$over aggradation and terrace formation, increase of slope $\left(\mathrm{s}^{+}\right)$, increase in depth $\left(\mathrm{d}^{+}\right)$, decrease in active channel width $\left(\mathrm{w}^{-}\right)$, and an overall significant reduction in channel capacity $\left(\mathrm{CC}^{--}\right)$; and (2) Upstream of Barrage - moderate reduction of flow competence ( $\mathrm{Q}^{-}$) and unchanging sediment load $\left(\mathrm{L}^{\circ}\right)$, the dominance of fluvial aggradation over the incision $\left(\mathrm{I}^{-}\right)$and longitudinal bar formation, a decrease of slope $\left(s^{-}\right)$, decrease in-depth $\left(d^{-}\right)$, increase in active channel width $\left(w^{+}\right)$, and overall moderate reduction in channel capacity $\left(C C^{-}\right)$.

It is observed that the Damodar river functionality level varies from poor to good-fair functionality level due to changing eco-geomorphological behaviour of the river system through anthropogenic intervention. So, the prominent impacts of dams and development have changed ecogeomorphological behaviour and fluvial Functionality of the Damodar River.

This study characterizes the eco-geomorphological behaviour and fluvial Functionality of Damodar River through this it identifies the ecological functionality level which is not supportive for the sustainability of the river environment. Measuring the ecological functionality level of the aquatic system is important for protecting the aquatic ecosystem and it is getting more importance in the world especially in the developed nations but this circumstance is not well inspiring for developing nations like India. So, intensive research is needed in some dimensions. For example, an environmental flow assessment is required for the aquatic environment. Hydrological and ecological data of more gauge stations are needed for assessing the environmental flow of the DRB. Recognizing the sources of diversion and alteration of flow concerning anthropogenic interventions

Page $15 / 28$ 
is required. For aquatic biota, research is needed due to the alteration of flow. Besides, research may be carried out on sediment movement and deposition concerning the evolution of aquatic biota. The research work should be done on these aspects in the context of West Bengal Rivers as well as Indian rivers. These aspects may also inspire other researchers and organizations from the various field of earth sciences.

\section{Declarations}

Availability of data and materials: The manuscript does not conatin any supplementary information with data and maps.

Competing Interests: The authors declare that they have no known competing financial interests or personal relationships that could have appeared to influence the work reported in this paper.

Funding: Not Applicable

Authors' Contributions: Sandipan Ghosh - Methodology and Conceptualization ; Md. Mofizul Hoque - Field data collection and data curation; Ujwal Deep Saha - Data mapping, software analysis; Aznarul Islam - Supervision, analysis of data and project administration

Acknowledgements: Not Applicable

\section{References}

1. Agarwal R, Sur K, Rajawat AS (2020) Accuracy assessment of the CARTOSAT DEM using robust statistical measures. Modeling Earth Systems and Environment 6: 471 - 426.

2. Bhattacharyya, K. (2011) The Lower Damodar River, India: understanding the human role in changing fluvial environment. Springer Science \& Business Media.

3. Bhattacharyya K, Singh VP (2019) Reservoir Sedimentation: Assessment and Environmental Controls. CRC Press, Boca Raton.

4. Biswas SS, Pani P (2021) Changes in the hydrological regime and channel morphology as the effects of dams and bridges in the Barakar River, India. Environmental Earth Science 80: 209. https://doi.org/10.1007/s12665-021-09490-0

5. Buffington JM, Mongomery DR (2013) Geomorphic classification of rivers. In: Shroder J, Wohl E (ed), Treatise on Geomorphology Vol 9 Fluvial Geomorphology, Academic Press. San Diego, pp. 730 - 767.

6. Bunn SE, Arthington AH (2002) Basin principles and ecological consequences of altered flow regimes for aquatic biodiversity. Environmental Management 30: 492 - 507.

7. Casado A (2013) Human impacts and fluvial metamorphosis: the effects of flood regulation on the hydrology, morphology and water temperature of the Sause Grande River, Argentina. Universite Blaise Pascal, Retrieved from www.tel.archives-ouvertes.fr/tel-01077867

8. Chow VT, Maidment DR, Mays LW (1988) Applied Hydrology. McGraw-Hill Book Company, New York.

9. De A K, Sen AK, Karim MR, Irgolic KJ, Chakraborty D, Stockton RA (1985) Pollution profile of Damodar River sediment in Raniganj-Durgapur industrial belt, West Bengal, India. Environmental International 11: 453 - 458

10. De AK, Sen AK, Modak A P (1980) Some industrial effluents in Durgapur and their impact on the Damodar River. Environmental International 4(2): $101-105$.

11. Dudgeon D (2000) The Ecology of Tropical Asian Rivers Andstreams in Relation to Biodiversity Conservation. Annual Review of Ecology and Systematics, 31, 239-263.

12. Friend and Sinha (2013) Braiding and meandering parameters. In: Best JL, Bristow CS (ed), Braided Rivers. Geological Society Special Publication No. 75, London, pp. 105 - 111.

13. Ghosh S (2011) Hydrological changes and their impact on fluvial environment of the lower Damodar basin over a period of fifty years of damming the mighty Damodar River in eastern India. Procedia Social and Behavioral Sciences 19: 511 - 519.

14. Ghosh S (2016) Present geomorphic categorization of alluvial channel reaches using channel dimensions and geomatics in the Damdoar River of West Bengal, India. In: Das BC et al. (ed), Neo-thinking on Ganges-Brahmaputra Delta, Springer, Switzerland, pp. 43 - 64.

15. Ghosh S, Guchhait SK (2014a) Hydrogeomorphic variability due to dam constructions and emerging problems: a case study of Damodar River, West Bengal, India. Environment Development and Sustainability 16: 769-796. https://doi.org/10.1007/s10668-013-9494-5

16. Ghosh S, Guchhait SK (2014b) Analyzing fluvial hydrological estimates and flood geomorphology from channel dimensions using ASTER DEM, GIS and statistics in the controlled Damodar River, India. Journal of Geomatics 8(2): 232 - 245.

17. Ghosh S, Guchhait SK (2016) Dam-induced changes in flood hydrology and flood frequency of tropical river: a study in Damodar River of West Bengal, India. Arabian Journal of Geosciences 9: 90, doi: 10.1007/s12517-015-2046-6

18. Ghosh S, \& Mistri B (2013) Performance of D.V.C. in Flood Moderation of Lower Damodar River India and Emergent Risk of Flood. Eastern Geographer, 19, 55-66.

Page $16 / 28$ 
19. Goldenberg-Vilar A, Delgado C, Peñas F, \& Barquín J (2021) The effect of altered flow regimes on aquatic primary producer communities: Diatoms and macrophytes. Ecohydrology. https://doi.org/10.1002/eco.2353

20. Graf WL (2006) Downstream hydrologic and geomorphic effects of large dams on American rivers. Geomorphology 79(3-4): 336-360. https://doi.org/10.1016/j.geomorph.2006.06.022

21. Karim S, De SK (2019) Impact of dam on river discharge: a study on the Damodar River, Jharkhand. Journal of Indian Geomorphology 6: 116 $-124$.

22. Krchnak K, \& Thomas G (2009) IntegratIng environmental Flows into Hydropower dam planning, design, and operations.https://www.researchgate.net/publication/238728244

23. Ligon FK, Dietrich WE, Trush, WJ (1995) Downstream ecological effects of dams - A geomorphic perspective. BioScience 45(3): $183-192$. https://doi.org/10.2307/1312557

24. Lin Q (2011) Influence of Dams on River Ecosystem and Its Countermeasures. Journal Of Water Resource And Protection, 03(01), 60-66. https://doi.org/10.4236/jwarp.2011.31007

25. Meehan MA, O'Brien PL (2019) Using the Rosgen stream classification system to aid in riparian complex ecological site descriptions development. Rangeland Ecology and Management 72 (5): 729 - 735.

26. Miller JR, Miller SMO (2007) Contaminated Rivers. Springer, Dordrecht.

27. Mitra S, Singh A (2018) Assessment of environmental flow requirements of Damodar River Basin by using flow duration indices method - a case study. International Journal of Hydrology 2(3): 281 - 283.

28. Monastersky R (2015) The human age. Nature 519(7542): 144-147. https://doi.org/10.1038/519144a

29. Nanson GC, Croke JC (1992) A genetic classification of floodplains. Geomorphology 4: 459 - 486.

30. Opperman JJ, Kendy E, Barrios E (2019) Securing environmental flows through system reoperation and management: Lessons from case studies of implementation. Frontiers in Environmental Science 7(JUN): 1-16. https://doi.org/10.3389/fenvs.2019.00104

31. Pal S( 2015) Impact of Massanjore Dam on Hydro Geomorphological Modification of Mayurakshi River Eastern India. Springer Science Business Media Dordrecht, 921-944.

32. Pal S, Biswas SS, Mondal B, Pramanik MK (2015) Effects of rainfall variability and barrage construction on discharge and channel modification in the lower Damdoar River, India. International Journal of Environmental Engineering Researches 4(2): 35 - 43.

33. Parks NSWN, Service W, \& Box PO (2000) Kingsford-2000-Austral_Ecology. Austral Ecology, 25, 109-127.

34. Resh VH, Brown AV, Covich AP, Gurtz ME, Li HW, Minshall GW, Wissmar RC (1988) The Role of Disturbance in Stream Ecology. Journal of the North American Benthological Society 7(4): 433-455. https://doi.org/10.2307/1467300

35. Richter BD, Thomas GA (2007) Restoring environmental flows by modifying dam operations. Ecology and Society $12(1)$. https://doi.org/10.5751/ES-02014-120112

36. Singh RK, Kumar Villuri VG, Pasupuleti S, Nune R (2020) Hydrodynamic modeling for identifying flood vulnerability zones in lower Damodar river of eastern India. Ain Shams Engineering Journal, 11(4): 1035-1046. https://doi.org/10.1016/j.asej.2020.01.011

37. Rosgen DL (1994) A classification of natural rivers. Catena 22: 169 - 199.

38. Schumm SA (1988) Patterns of alluvial rivers.Annual Review of Earth and Planetary Sciences 13: 5 - 27.

39. Schumm SA (1969) River metamorphosis. Journal of the Hydraulics Division 95(1): 255 - 274.

40. Schmutz S, Moog O (2018) Dams: Ecological Impacts and Management. In: Schmutz S., Sendzimir J. (eds) Riverine Ecosystem Management. Aquatic Ecology Series, vol 8. Springer, Cham. https://doi.org/10.1007/978-3-319-73250-3_6

41. Siligardi M (2007) Fluvial functionality index (FFI) version 2007. Centro ItalianoStudi di BiologiaAmbietale, Roma.

42. Siligardi M, Cappelletti C (2006) A new approach to evaluating fluvial functioning (FFI): towards a land scape ecology. In: Ziglio G, Siligardi M, Flaim G (ed), Biological Monitoring of River, John Wiley \& Sons Ltd., New York, pp. 401 - 418.

43. Singh RK, Villari VGK, Pasupulrti S, Nune R (2014) Hydrodynamic modeling for identifying flood vulnerability zones in lower Damodar River of eastern India. Ain Shams Engineering Journal 11: 1035 - 1046.

44. Suwal N, Kuriqi A, Huang X, Delgado J, Młyński D and Walega A (2020) Environmental Flows Assessment in Nepal: The Case of Kaligandaki River. Sustainability, 12(21), p.8766.

45. Tare V, Gurjar SK, Mohanta H, Kapoor V, Modi A, Mathur RP, Sinha R (2017) Eco-geomorphological approach for environmental flows assessment in monsoon-driven highland rivers: A case study of Upper Ganga, India. Journal of Hydrology: Regional Studies 13(November 2016): 110-121. https://doi.org/10.1016/j.ejrh.2017.07.005

46. Thoms MC, Parsons M (2002) Eco-geomorphology: An interdisciplinary approach to river science. IAHS-AISH Publication (276): 113-11

47. USDA (2007) Rosgen geomorphic channel design. NRCS Stream Restoration Design National Engineering Handbook Part 654.

48. Vinh VD, Ouillon S, Thanh TD, Chu LV (2014) Impact of the Hoa Binh dam (Vietnam) on water and sediment budgets in the Red River basin and delta. Hydrology and Earth System Sciences 18(10): 3987-4005. https://doi.org/10.5194/hess-18-3987-2014

Page $17 / 28$ 
49. Verma RK, Murthy S, Tiwary RK (2015) Assessment of environmental flows for various sub-watersheds of Damodar River Basin using different hydrological methods. International Journal of Waste Resources 5(4): 1 - 6.

50. Verma RK, Murthy S, Verma S, Mishra SK (2017) Design flow duration curves for environmental flows estimation in Damodar River Basin, India. Applied Water Science 7: 1283 - 1293.

51. Vucijak B, Zvanut NS, \& Antonelli F (2015) Development of Environmental Flow Assessment Procedure For Bosnia and Herzegovina. The 12th Conference on Sustainable Development of Energy, Water and Environment Systems, 1-8. https://www.researchgate.net/publication/267421066

52. Ward JV (1989) The four-dimensional nature of lotic ecosystems. Journal of the North American Benthological Society 8(1): 2-8.

53. Wiejaczka $Ł$, Bucała A, Sarkar S (2014) Human role in shaping the hydromorphology of Himalayan rivers: Study of the Tista River in Darjeeling Himalaya. Current Science 106(5): 717-724. https://doi.org/10.18520/cs/v106/i5/717-724

54. Zhong Y, Power G (1996) Some environmental impacts of hydroelectric projects on fish in canada. Impact Assessment 14(3): $285-308$. https://doi.org/10.1080/07349165.1996.9725905

\section{Figures}

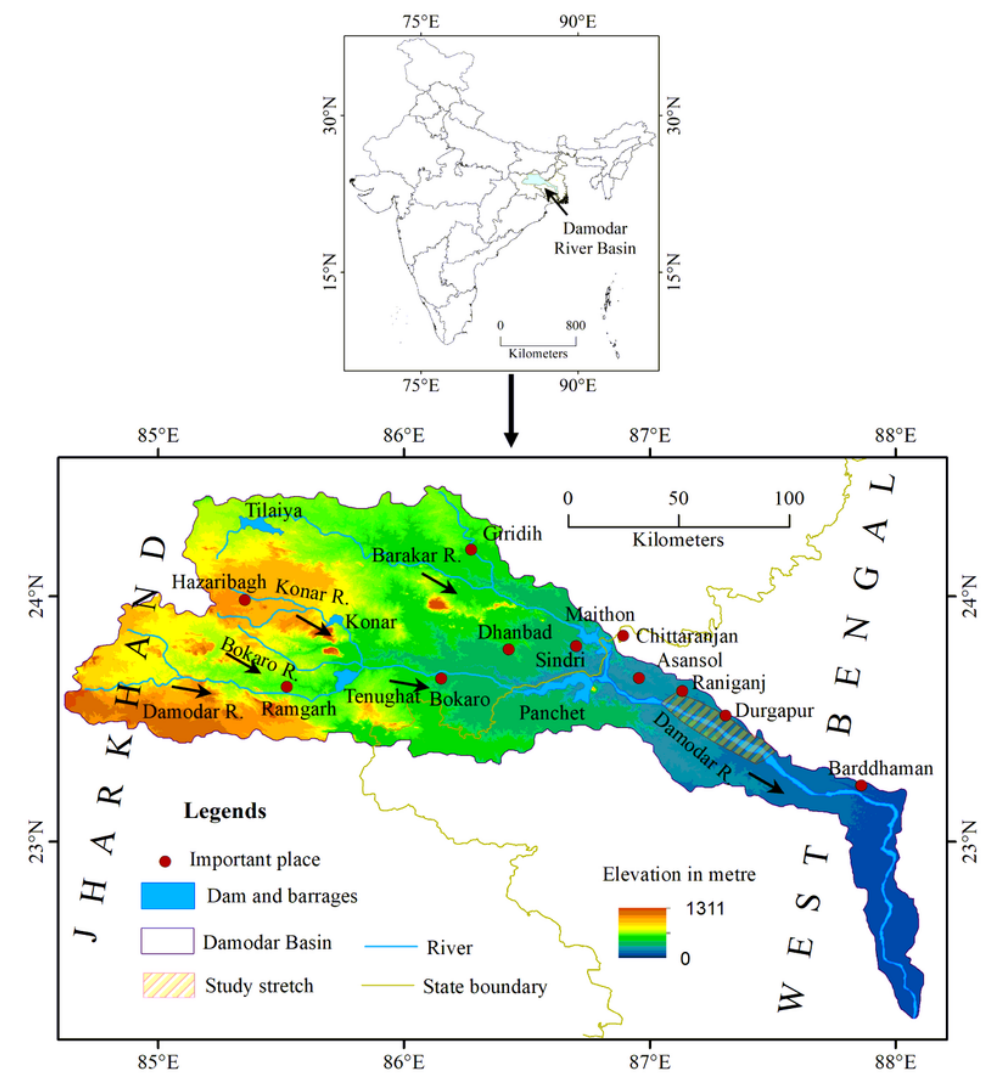

\section{Figure 1}

Location of the study area 
(a) Cross-Profile of Channel (Downstream)
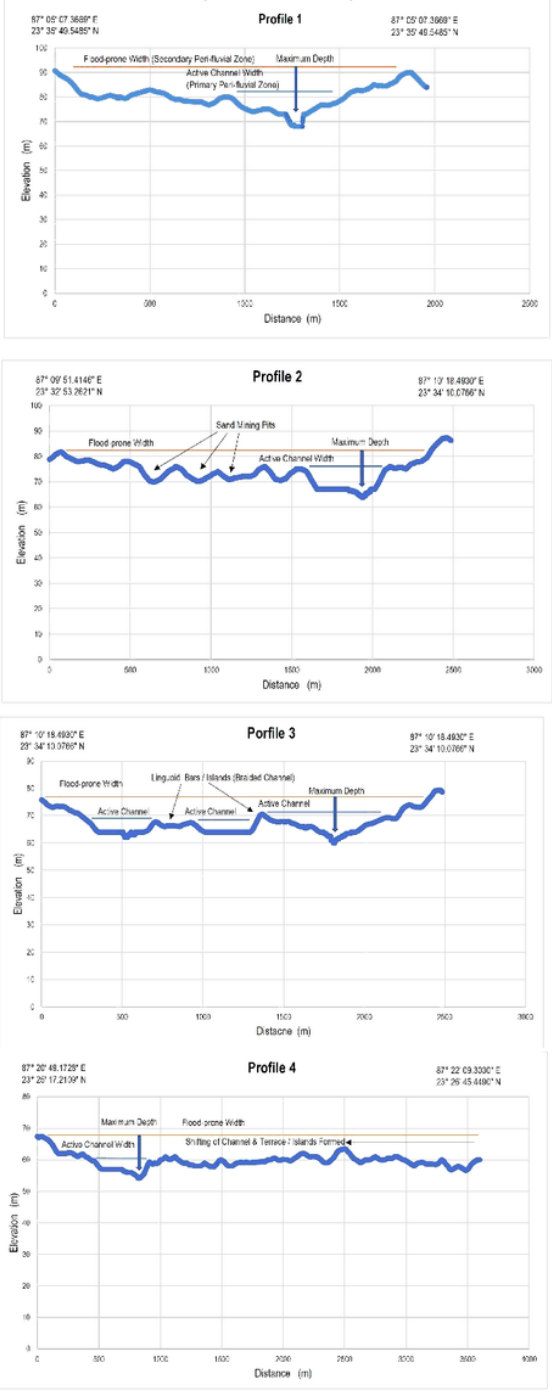

Figure 2

(a) Downstream cross-profiles of Damodar River derived from the laser auto level survey (February, 2021), showing key geomorphic features (maximum depth of thalweg, active channel width, flood-prone width, bed topography, braiding and shifting of channel); and (b) field photographs showing survey work in sandy channel bed, bank erosion, abandoned channel and agricultural land use. (b) Field Survey \&

Validation
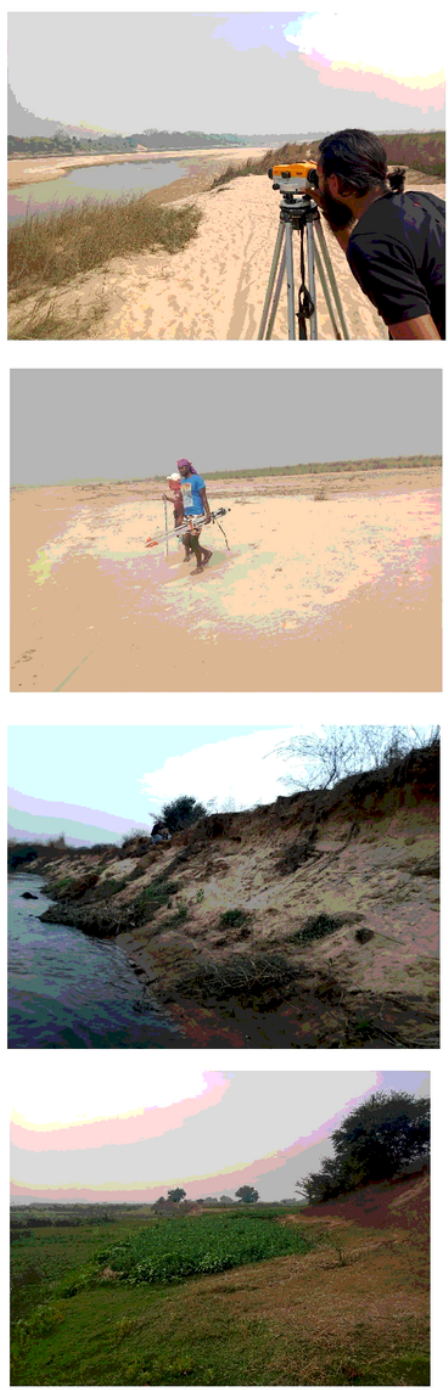


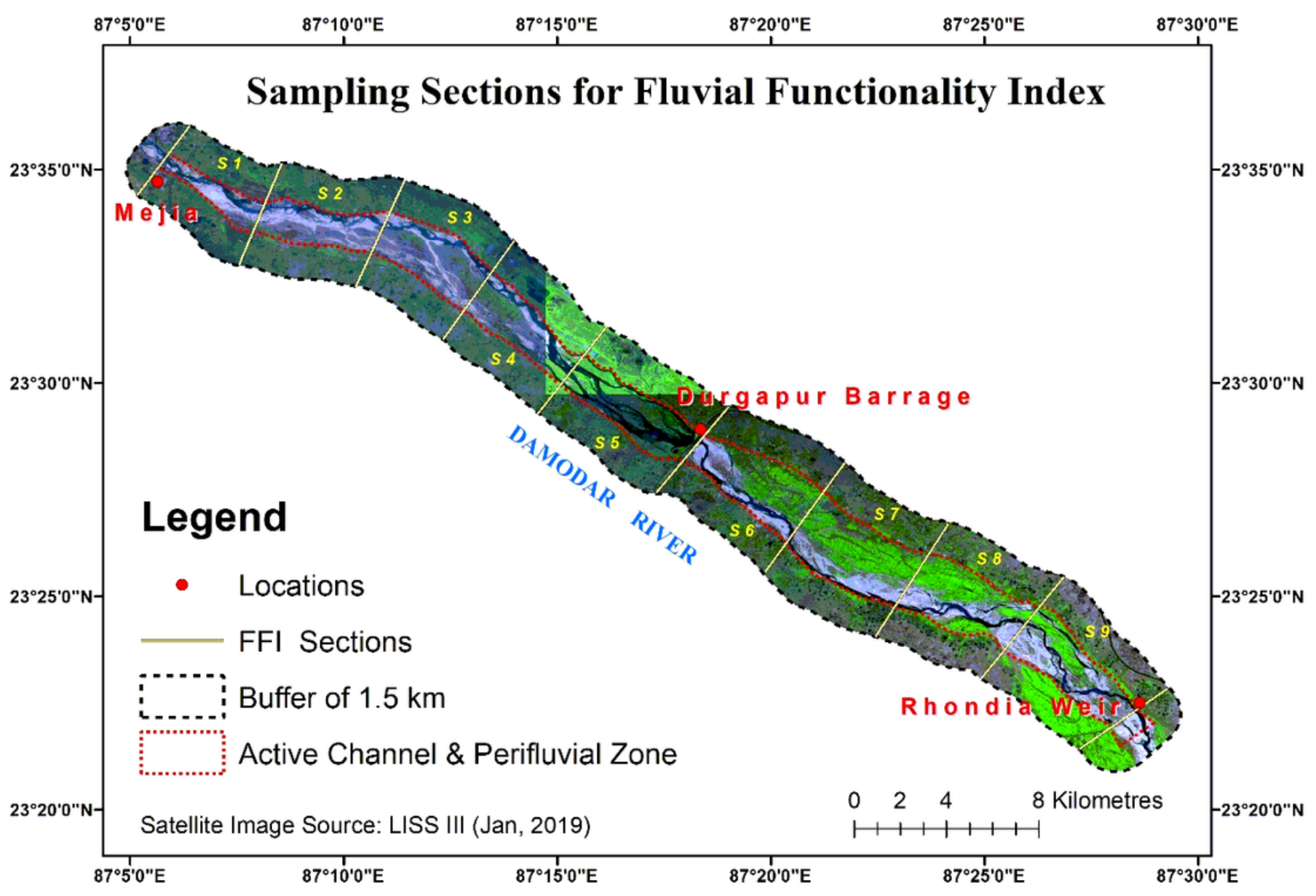

Figure 3

The survey reach (i.e., $47 \mathrm{~km}$ stretch subdivided into homogenous ninesections or units, S1 to S9) of Damodar River selected for the assessment of fluvial functionality, showing buffer zone, active channel andperifluvial zone,and location of Durgapur Barrage (taking into consideration for assessing the impact of river impoundment) 


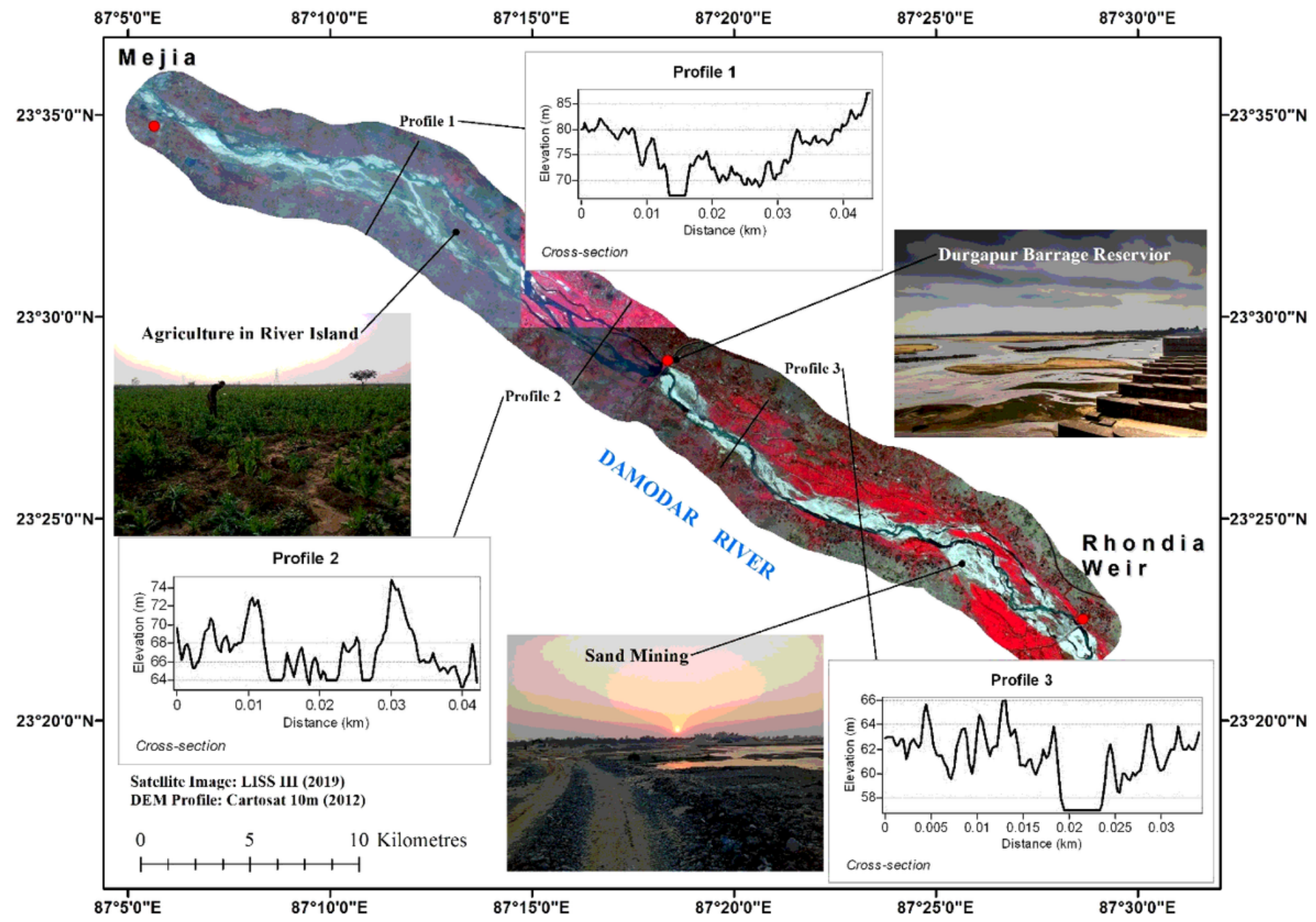

Figure 4

The thematic map showing downstreamand upstream variation of DEM channel cross-sections associated with field photographs (for understanding ground condition): profile 1 - in-channel sedimentation, wide valley, islands/bars formation and slight braiding; Profile 2: elevated embankment, confinement of river and high degree of braiding; and Profile 3: narrowing of channel, agriculture use of river islands, terrace formation and shifting course towards right bank 


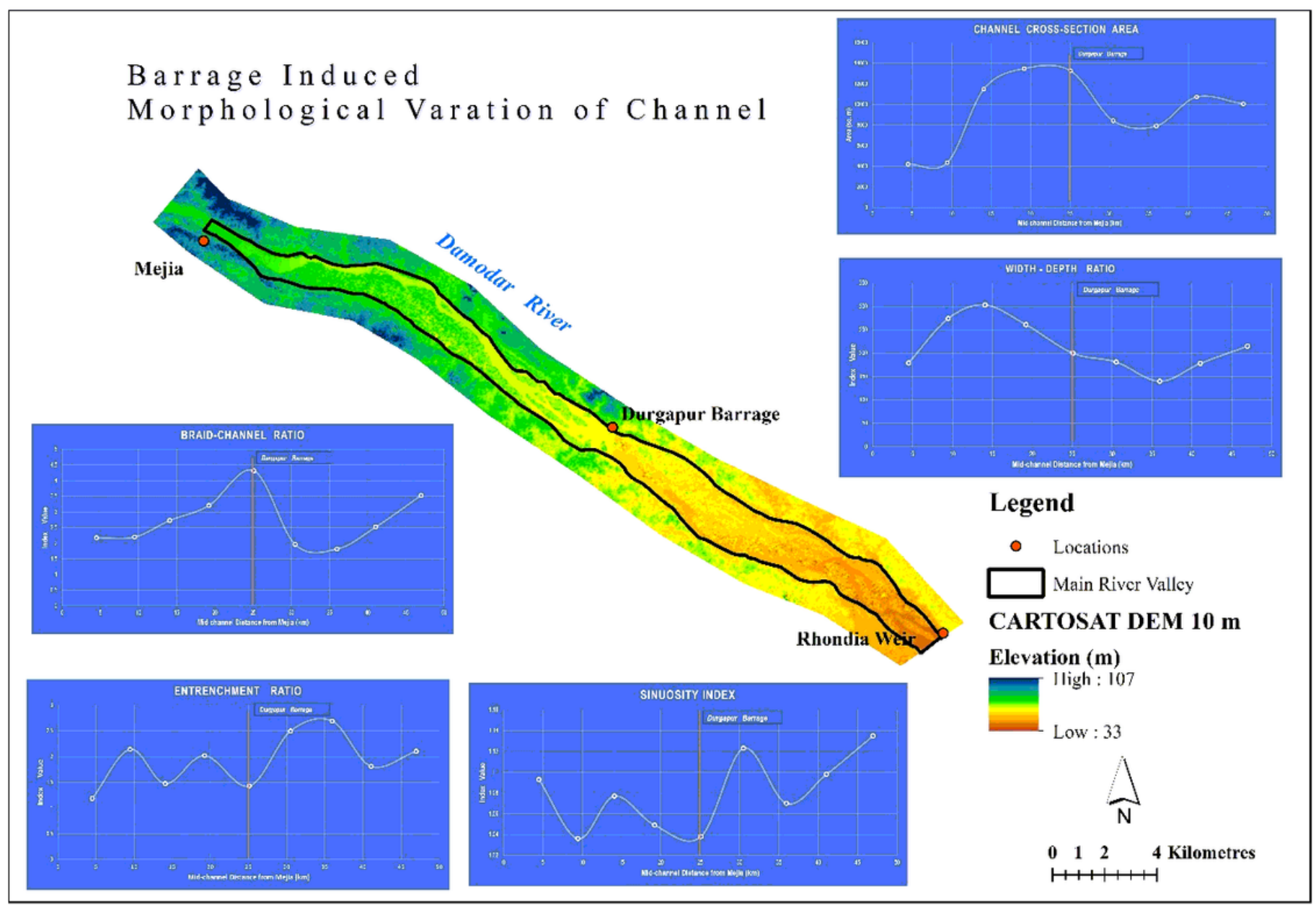

Figure 5

The thematic map showing elevation anomalies of Damodar valley (33 to $107 \mathrm{~m}$ ) and barrage induced upstream / downstream variation of channel dimensions, viz., channel cross-section area (high at upstream of barrage), width-depth ratio (high at upstream and compatible to accommodate high discharge), braid-channel ratio (maximum near the barrage due to highest numbers of bars), entrenchment ratio (variable throughout the reach but high at downstream due to flow incision), and sinuosity index (variable but low deviation and maintain linearity due to lineament). 


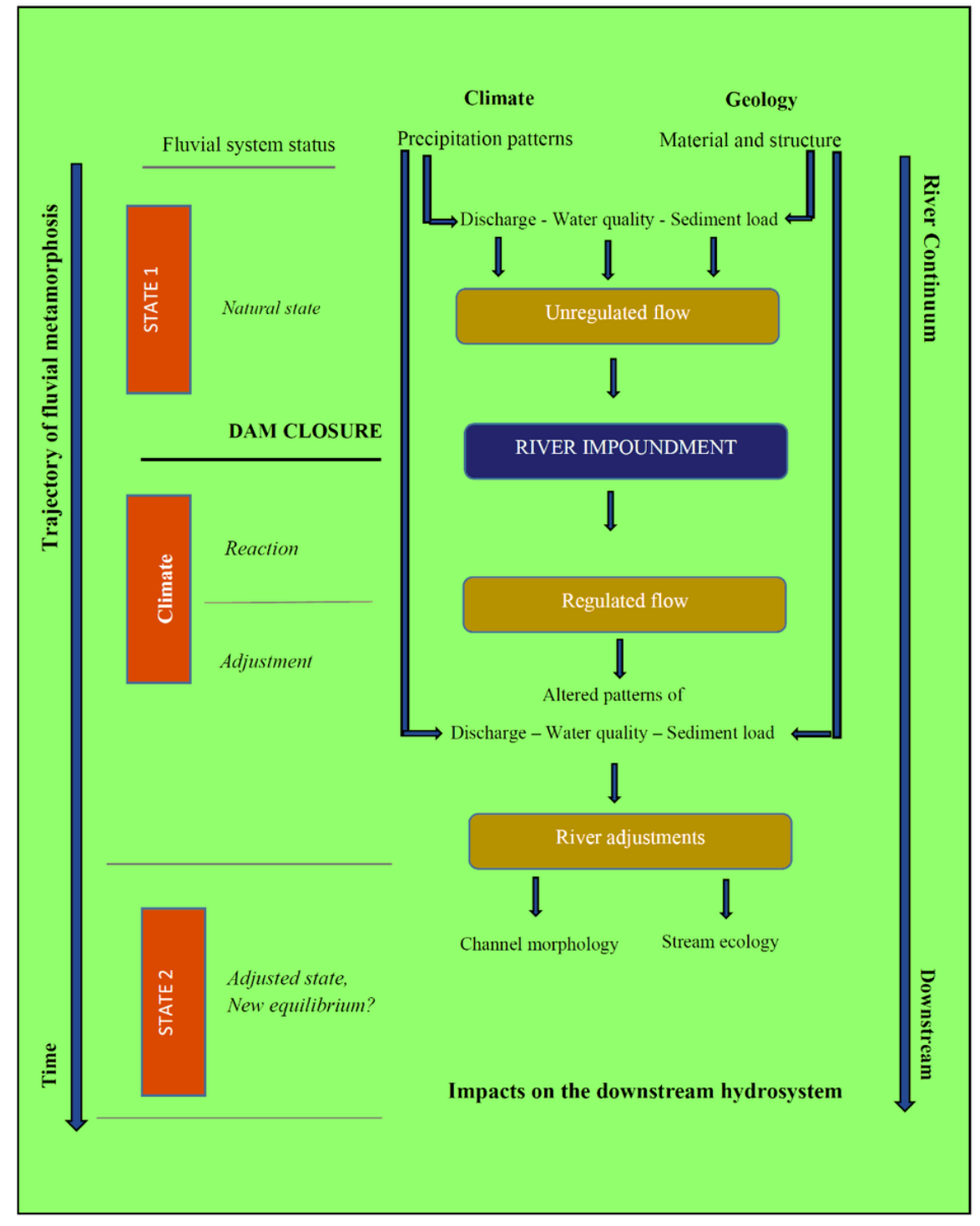

Figure 6

Possible impacts of river impoundment on fluvial metamorphosis through time 


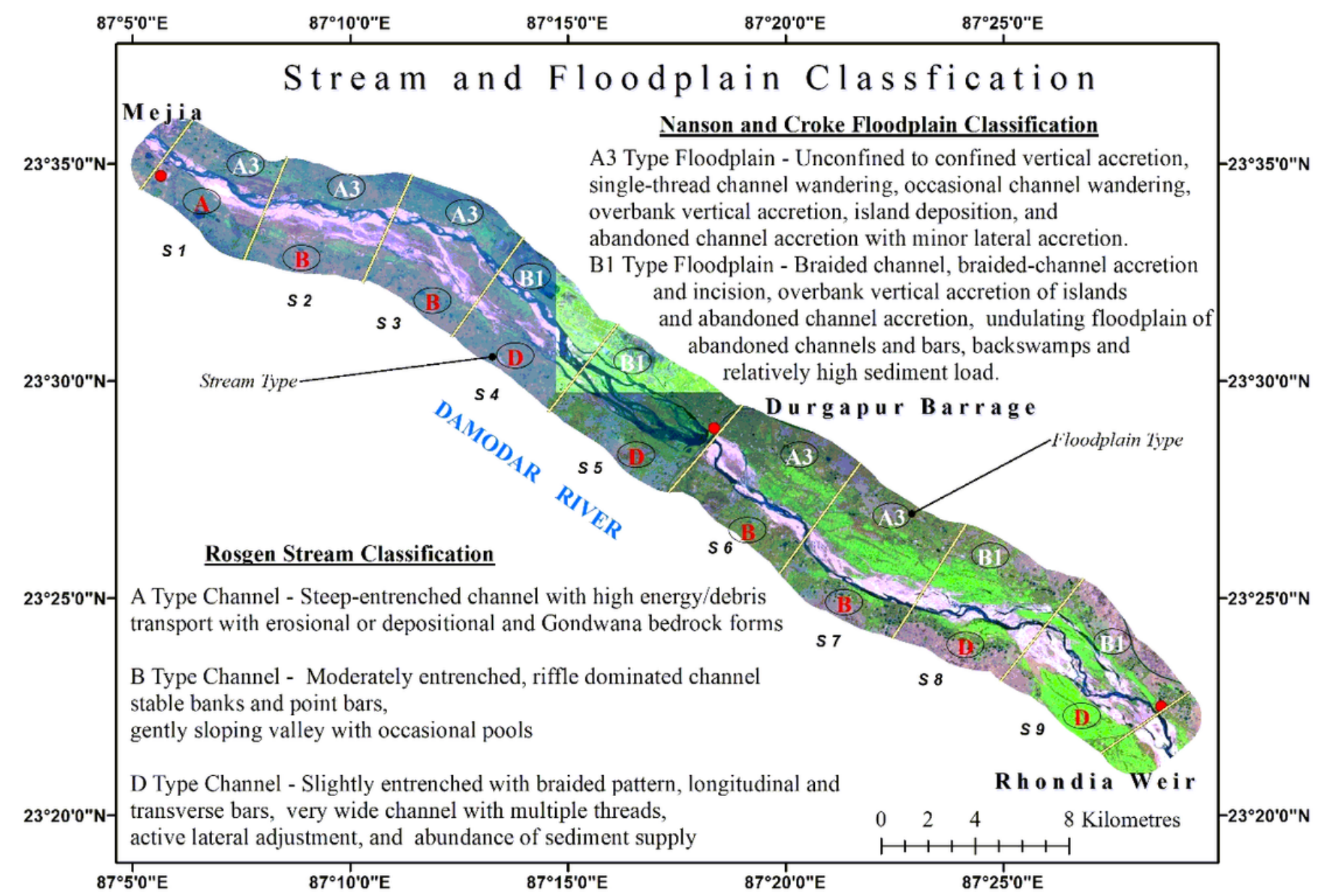

Figure 7

Final thematic map of stream and floodplain classification depicting upstream to downstream (fluvial response tothe Durgapur Barrage reservoir) changes in the recognizedRosgenstream types $(A \rightarrow B \rightarrow D \rightarrow B \rightarrow D$ types) and Nanson - Croke floodplain types ( $A 3 \rightarrow B 1 \rightarrow A 3 \rightarrow B 1$ types) 

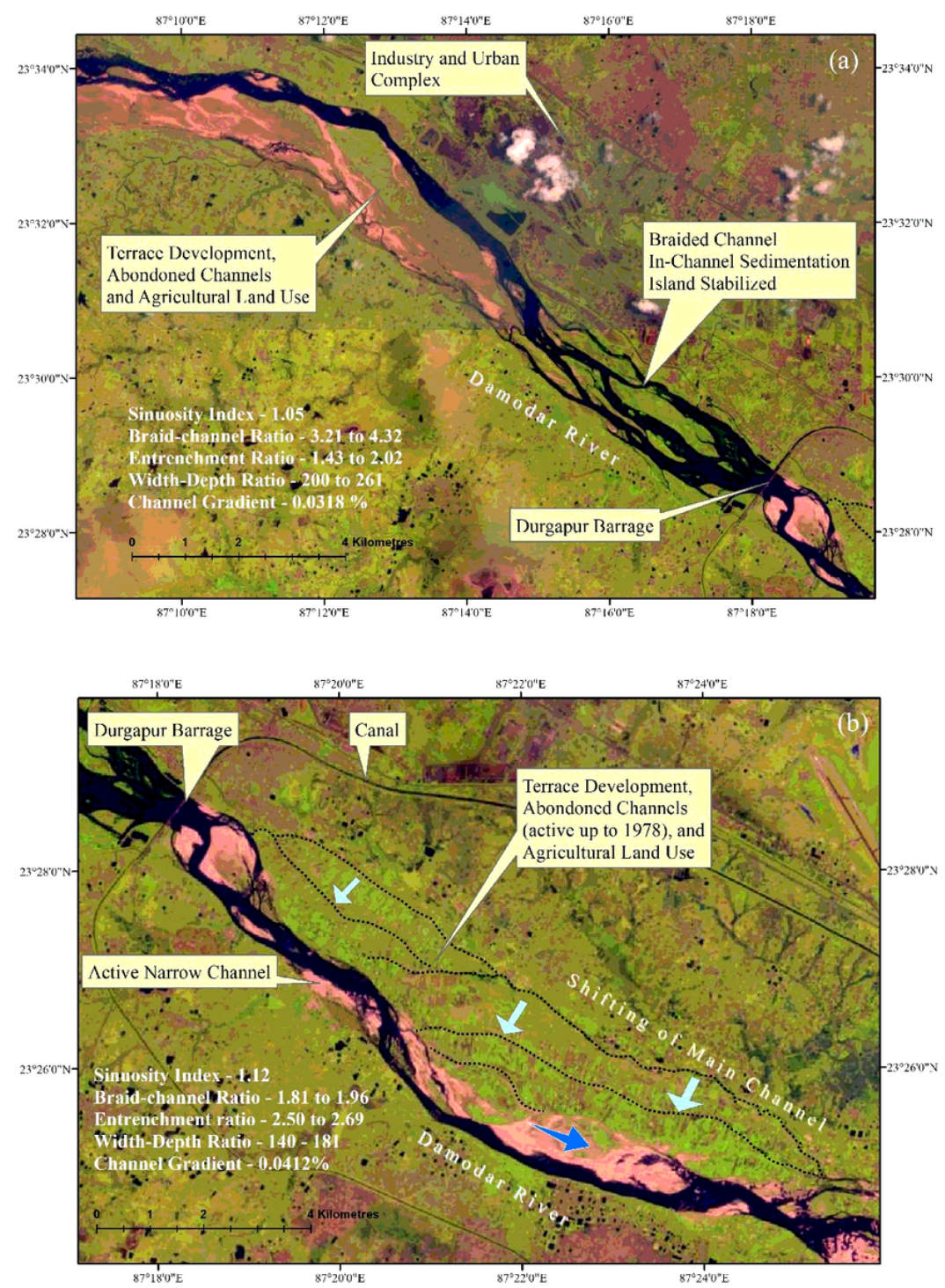

\section{Figure 8}

Observed imprints of river metamorphosis in the controlled Damodar River: (a) upstream of the barrage (D type channel, i.e., slightly entrenched with braided pattern) - increasing sediment load, valley widening, high width-depth ratio, in-channel sedimentation, high tendency of braiding, low level of entrenchment and river confinement due to urban-industrial complex; and (b) downstream of the barrage (B type channel, i.e., moderately entrenched narrow channel) - narrow channel, immediate fluvial incision, abandoned channels, terrace development and right bank shifting of main flow, low width-depth ratio, and intensive agricultural use of islands 


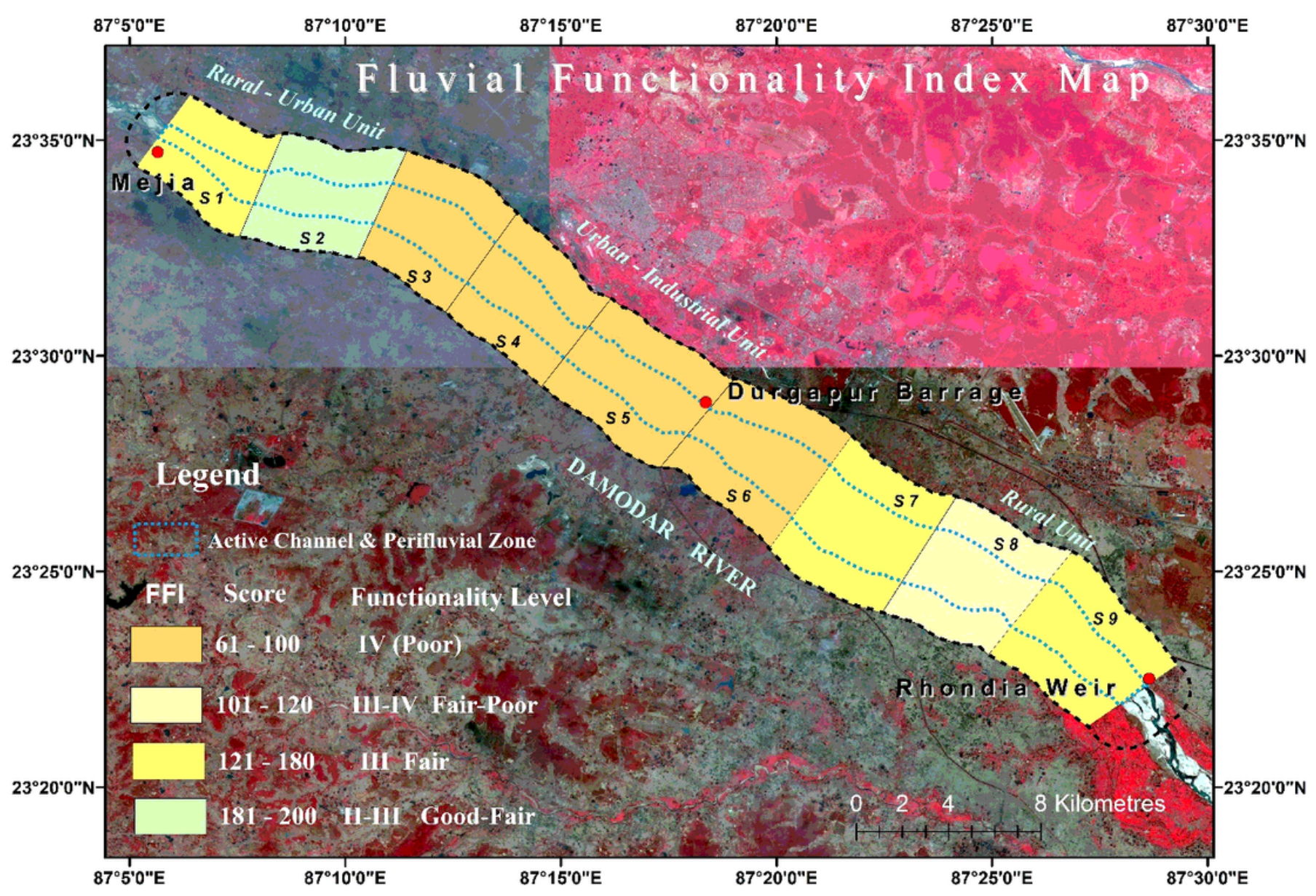

Figure 9

Fluvial functionality index map of the Damodar River showing four recognized ecological functionality level (i.e., Poor to Good-Fair category) as fluvial response to river impoundment (immediate upstream and downstream of the barrage), changing hydrological regime (flow variability and hydrogeomorphic attributes) and other anthropogenic interferences (urban and rural land uses)

展

\section{Figure 10}

Environmental fragileness in the Damodar River: (a) and (b) Durgapur Barrage reservoir is recognized as Important Bird Area (IBA) of India, supporting numerous avania species (e.g., colony of Ruddy Shelduck and Small Pratincole, migrated in winter months); (c) Osprey, a migratory raptor, feeding its kill with presence of anthropogenic disturbance in the river bed (i.e., carrier trucks in sand mining pits and multi-storeys buildings at backdrop), (d) intensive sand mining in main channel near Rhondia, (e) imprint of fly ash on the sediment layer through Tamla nala, down Durgapur barrage near Mejia, (f) high level of eutrophication in stagnant channel near Waria, $(\mathrm{g})$ and $(\mathrm{h})$ inflow of urban-industrial effluents into the main Damdoar through Singaran Nala Tamlanala, Durgapur 


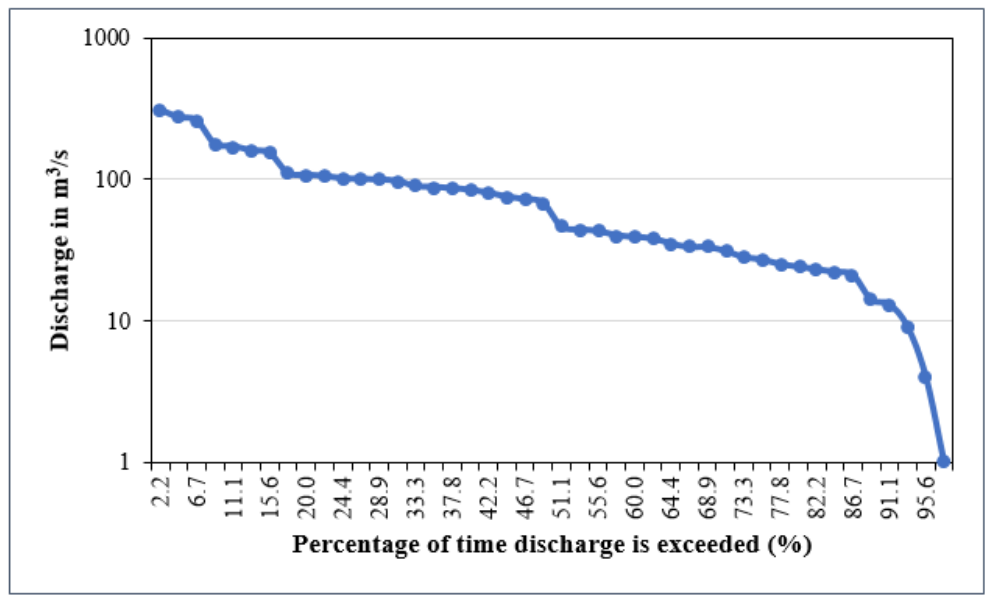

a

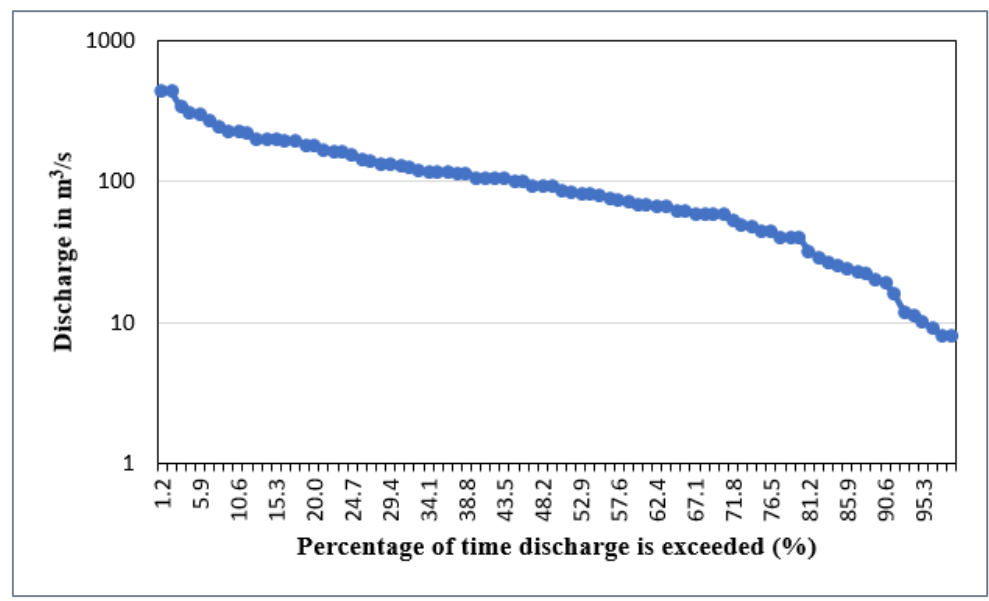

b

\section{Figure 11}

a: Flow duration curve of 22 years discharge data at Rhondia of Damodar River with respect to monthly average streamflow of lean period ( December to May) in the pre-dam period (Based on Bhattacharyya, 2011) b: Flow duration curve of 42 years discharge data at Rhondia site of Damodar River with respect to monthly average streamflow of lean period ( December to May) in the post-dam period (Based on Bhattacharyya, 2011) 


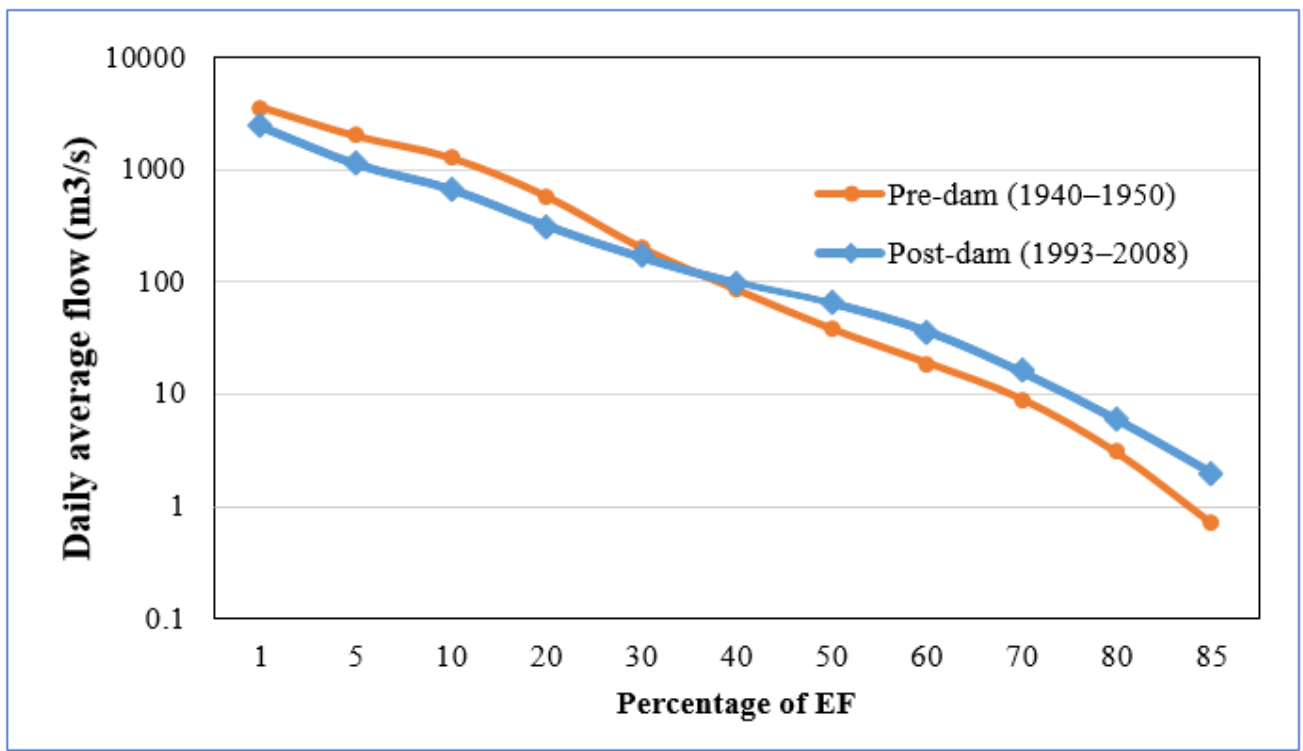

Figure 12

Flow duration curve of Damodar River at Rhondia site in pre- and post-dam periods with respect to daily average flow (Based on Bhattacharyya, 2011) 